\title{
Atlas and Hercules in the Garden
}

Scientific Culture and Literary Imagination

at the Villa Aldobrandini at Frascati

\author{
Denis Ribouillault \\ University of Montréal, Canada \\ denis.ribouillault@umontreal.ca
}

\begin{abstract}
This essay explores the interplay in early modern Roman gardens between the iconography of instruments and fountains and scientific culture, especially astronomy. Examining the sundials that adorned the garden at the Villa Aldobrandini at Frascati, it suggests a new reading of the garden and its iconographic programme, centred on the iconography of Atlas and Hercules holding the celestial sphere. It stresses the importance of scientific culture for both the conception and the subsequent reception of the programme. Several themes are developed: the relevance of wonder and curiosity in the process of understanding nature, the multiple links between nature and artefacts in the space of the garden, and the scientific interests of the patron, Cardinal Pietro Aldobrandini, and his main adviser, the letterato Giovanni Battista Agucchi.
\end{abstract}

\section{Keywords}

gardens - Giovanni Battista Agucchi - sundials

\section{For Volker Remmert}

In Galileo as a Critic of the Arts (1954), Erwin Panofsky famously advanced the contention that it was Galileo's aesthetic taste that explained his refusal to con- 
sider Kepler's discovery of the elliptical orbit. The ellipse, he argued, was too foreign to the idea of perfection represented by the circle. It was, he wrote, "[...] something incompatible with the very principles which dominated his thoughts as well as his imagination."1 In other words, Galileo was a "purist," a "classicist," with a "mortal aversion to 'impure music', allegorical poetry, perspective anamorphosis and double images [...] which made it impossible for him to visualise the solar system as a combination of ellipses." That an art historian could explain such a puzzling fact in the history of science has been considered one of the most interesting paradoxes in the field since Alexandre Koyré's celebratory review of Panofsky's pamphlet in $1955 .{ }^{3}$ Even quite recently, another eminent historian of science could write, "[...] a study on Galileo and Kepler cannot but start with Panofsky."

Interestingly, Galileo's aesthetic attitude is also highly instructive for garden historians. In Considerazioni al Tasso, where he discusses the respective merits of Ariosto's and Tasso's poetry, he severely criticises the Palace and Garden of Armida described in Gerusalemme liberata (canto XVI), with the garden's "oblique and uncertain" roads and the "diabolical edifice" built in an "inscrutable, confused" order; he compares these with anamorphic images, similar to a "chaotic blend of lines and colours, whence with difficulty one can make out the images of rivers or tortuous alleys, barren shores, clouds, or wild fancies." He contrasts this "mannerist" garden to the verdant hanging garden in Logistilla's citadel in Ariosto's Orlando furioso or, in the same book, with the

1 I am grateful to the editors of the special issue and the two anonymous readers for Nuncius who all provided valuable feedback on the article and helpful suggestions for the translations from the Italian. Thanks are also due to Mandy MacDonald for editing my English. A preliminary version of this article was first presented at the Renaissance Society of America annual conference in New York in March 2014. Erwin Panofsky, "Galileo as a Critic of the Arts: Aesthetic Attitude and Scientific Thought," Isis, 1956, 47, 1:3-15, p. 11. Originally published as Galileo as a Critic of the Arts (The Hague: Martinus Nijhoff, 1954).

2 Ibid., p. 12.

3 Alexandre Koyré, "Attitude esthétique et pensée scientifique," Critique, 1955, 9:835-847.

4 Massimo Bucciantini, Galilée et Kepler. Philosophie, cosmologie et théologie à l'époque de la Contre-Réforme, translated by Gérard Marino (Paris: Les Belles Lettres, 2008), pp. xvi-xxii (xvi).

5 Galileo Galilei, Scritti letterari, edited by Alberto Chiari (Firenze: Le Monnier, 1970), p. 605. I quote the English translation given in Claudio Pizzorusso, "Galileo in the Garden: Observations on the Sculptural Furnishings of Florentine Gardens between the Sixteenth and Seventeenth Centuries," in The Medici, Michelangelo \& the Art of Late Renaissance Florence, exhibition catalogue (Art Institute of Chicago; Detroit Institute of Arts, 2002-2003), edited by Cristina Acidini Luchinat (New Haven: Yale University Press, 2002), pp. 112-121, p. 113.

NUNCIUS $30(2015) 124-160$ 
garden of the beautiful Alcina. ${ }^{6}$ In Galileo's critical insights, garden design is bound up with literary style, one being the mirror of the other, and Ariosto's prose is the clear winner with its precise and limpid style of argument.

That literary criticism, garden design and scientific culture should be so clearly entangled, as Galileo's oeuvre demonstrates, both complicates and enriches the task of garden historians. What it confirms is the idea that an interdisciplinary approach is necessary for the understanding of historic gardens and their reception at different moments in time, insofar as one believes that the garden is more than simply an art; rather it is, as Hervé Brunon has observed, "an aesthetic, social, and political phenomenon." As Pierre Grimal puts it, "Gardens of a given period are as indicative of the spirit of a time as its sculptures, its paintings or its literature can be."

Much has been written on the place literature held in the design and the function of gardens during the Renaissance. ${ }^{8}$ By contrast, perhaps with the exception of the botanical garden, the number of studies that have explored the interaction between the world of the garden and scientific culture is relatively limited. ${ }^{9}$ In this paper, I would like to propose a new way of thinking about gardens and the scientific imagination, by focusing on the links between early modern Roman gardens and astronomy. In order to avoid dissociating the epistemological culture of gardens from their material history, I take as a point of departure garden sundials - at once ornaments and instruments - and the astronomical imagery that often complemented them in the garden and the villa. Sundials are documented in the major Renaissance and Baroque gardens

6 Ariosto, Orlando furioso, X.61-63; viI.11-15.

7 Hervé Brunon, Pratolino: art des jardins et imaginaire de la nature dans l'Italie de la seconde moitié $d u X_{V I}^{e}$ siècle, PhD thesis, Université Paris 1 Panthéon-Sorbonne, revised edition 2008 [2001], p. 34; accessible at http://tel.archives-ouvertes.fr/tel-oo349346. Pierre Grimal, L'Art des jardins (Paris: Presses Universitaires de France, 1974), p. 7.

8 See most recently Hervé Brunon, "De la littérature au jardin," in Delizie in villa. Il giardino rinascimentale e i suoi committenti, edited by Gianni Venturi and Francesco Ceccarelli (Firenze: Olschki, 2008), pp. 5-31.

9 A few essential titles are: Eugenio Battisti, L'antirinascimento (Milano: Feltrinelli, 1962); Philippe Morel, Les grottes maniéristes en Italie au XVIe siècle. Théâtre et alchimie de la nature (Paris: Macula, 1998); Michel Baridon, "The Scientific Imagination and the Baroque Garden," Studies in the History of Gardens \& Designed Landscapes: An International Quarterly, 1998, 18, 1:5-19; as well as Volker Remmert's studies on the interactions existing between the world of mathematicians and that of gardeners in the early modern period. See, for example, his "Hortus mathematicus: über Querverbindungen zwischen Gartentheorie und praxis und den mathematischen Wissenschaften in der Frühen Neuzeit," Wolfenbütteler Barock-Nachrichten, 2004, 37:3-24. 
of Rome and its Campagna, yet they have never been the subjects of enquiry per se. ${ }^{10}$ How were such measuring instruments considered within the space of the garden? What was their meaning, their function? During a period of great significance in the history of science, did they help visualise or articulate new knowledge about the physical world? How did they interact with the rest of the garden? What can the study of these objects tell us about science? Within the restricted scope of this essay, I propose to address these questions by examining one specific case study: that of the Villa Aldobrandini at Frascati. I will suggest a new reading of the garden and its iconographic programme, stressing the importance of scientific culture for both its conception and its subsequent reception.

\section{The Sundials at Villa Aldobrandini}

Sundials in gardens appear on the title pages of important scientific books in the early modern period, notably those by the Jesuits Mario Bettini and Athanasius Kircher. On the frontispiece of Bettini's Apiaria (1642), a sundial occupies the field in front of a fountain symbolising immortality and everlasting life (Fig. 1). ${ }^{11}$ The sundial's hour lines appear to have been made of strips of lawn or grass, and a cypress tree is used as a gnomon. Beehives in the shape of vases, corresponding to the ten sections of the Apiaria, are decorated with pictures illustrating the different branches of the mathematical sciences: arithmetic, geometry, cosmography, optics, music, architecture, astronomy, mechanics, hydrology and fortification. The sundial refers to the ninth section of the Apiaria, dedicated to the theory of sundials, which John Evelyn mentioned later in his treatise on gardens, Elysium Britannicum. ${ }^{12}$ The frontispiece of Kircher's Ars magna lucis et umbrae (1646) shows another ideal hortus mathematicus,

10 See now Denis Ribouillault, "Julius III's Tower of the Winds: a Forgotten Aspect of Villa Giulia," in Renaissance Studies in Honor of Joseph Connors, edited by Machtelt Israëls and Louis A. Waldman, 2 vols., Vol. I (Cambridge, MA: Harvard University Press, 2013), pp. 474-484; and Id., "Sundials on the Quirinal: Astronomy and the Early Modern Garden," in Gardening and Knowledge. Landscape Design and the Sciences in the Early Modern Period, edited by Hubertus Fischer, Volker Remmert and Joachim Wolschke-Bulmahn (Basel: Birkhäuser Verlag, 2015, forthcoming).

11 On Bettini's frontispiece, see Volker Remmert, Picturing the Scientific Revolution: Title Engravings in Early Modern Scientific Publications, translated by Ben Kern (Philadelphia: Saint Joseph's University Press, 2011), pp. 214-228.

12 Ibid., p. 218.

NUNCIUS $30(2015) 124-160$ 


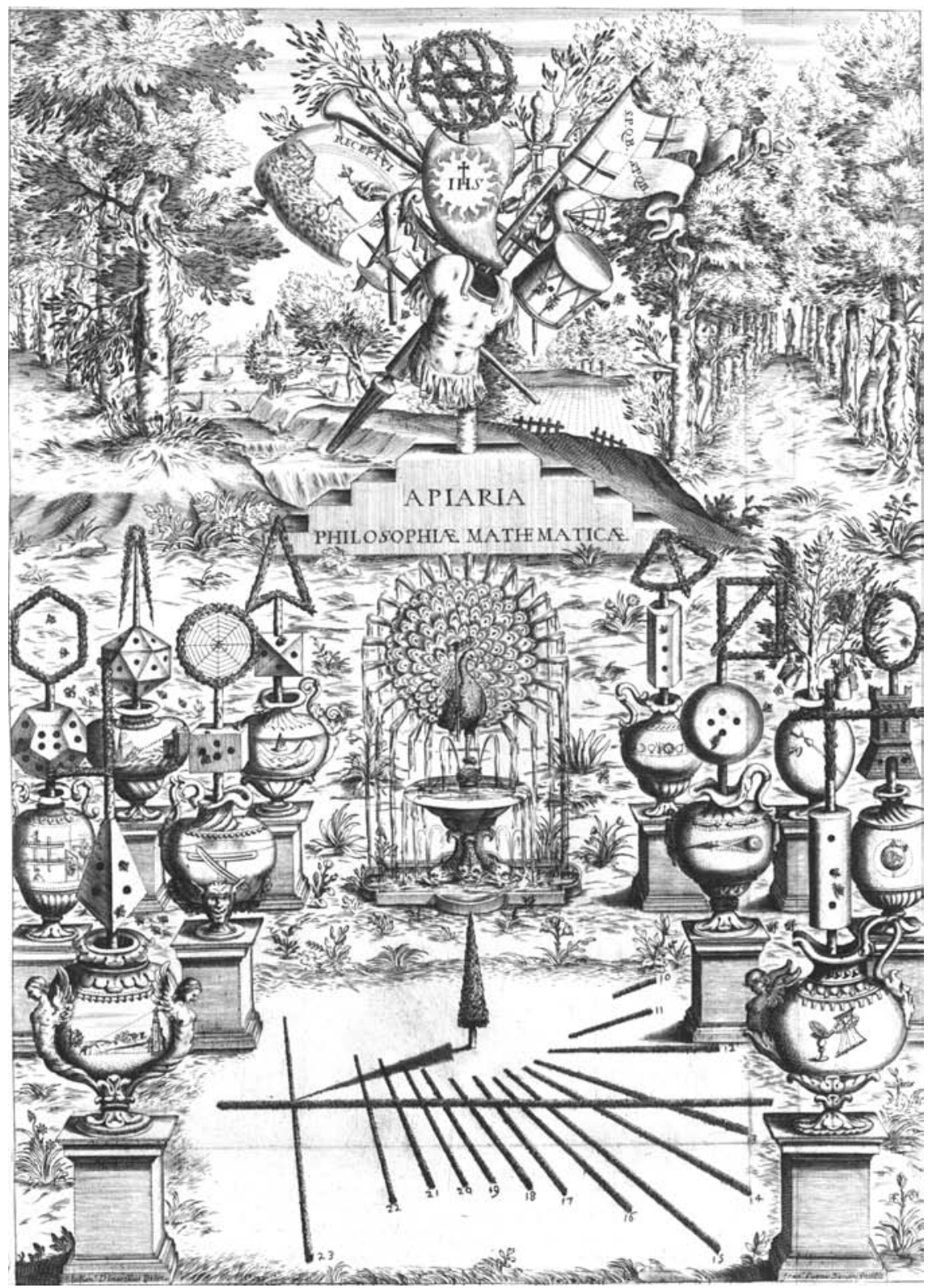

FIGURE 1 Mario Bettini, Apiaria (Roma, 1642), frontispiece by Giuliano Dinarelli and Francesco Curti (Photo: Volker Remmert) 
with a floral sundial, a dioptric sundial, a helioscope and a catoptric sundial in a garden grotto (Fig. 2).13 The floral sundial occupies one of the squares of the garden parterre in front of the villa, with a small obelisk standing as the gnomon or indicator. Besides presenting a vast array of scientific instruments, Kircher's title page is revealing about the Jesuit's view of human knowledge. On the lower right side of the page is Sensus, or sensory perception, and on the opposite side Auctoritas profana, referring to pagan philosophers such as Aristotle. In the upper, spiritual part of the image, lit by divine light, are Auctoritas sacra (the Holy Scriptures) and Ratio (Reason). Here, Kircher clearly subordinates philosophy and sensory perception to reason and the authority of the holy scriptures in defining human knowledge, an epistemological hierarchy which had been heavily challenged by Galileo and some of his followers in the previous decades.

These images show that gardens were a privileged space for the practice of science and for enquiring about the natural world. As such, Bettini's and Kircher's mathematical gardens can be compared to theatres, an important topos for Renaissance gardens; that is, spaces where knowledge is organised and displayed. At the same time, the elaborate, beautifully crafted instruments invited spectators to marvel at and delight in the intimate interplay of art and nature that the garden revealed in all its parts. In other words, these imaginary sundials led their viewers to wonder, in both senses of the word. They made clear the scientific content of the books, but were inseparable from the sensuous dimension associated with the garden. To historians today, they also suggest that real gardens were equipped with such instruments. In his treatise Le théâtre d'agriculture (1600), Olivier de Serres states clearly that any obelisk, column or even tree could be used as a gnomon:

Some, in the middle and at the corners of compartments, plant small trees protruding upward. In doing so, they are mistaken. For, believing that they make the compartment more graceful, they in fact diminish its beauty. If however, one wishes to plant such trees, one must choose the least leafy trees and those whose trunks rise high and straight, such as the cypress tree, which is above all the most suitable for this purpose. And it is fitting that it be used as a gnomon in the centre of a parterre shaped like a dial, marking the hours. Instead of trees, one may use rare antiques; statues, columns, pyramids, obelisks and other similar pieces made of marble,

13 Ibid., pp. 69-72.

NUNCIUS $30(2015) 124-160$ 


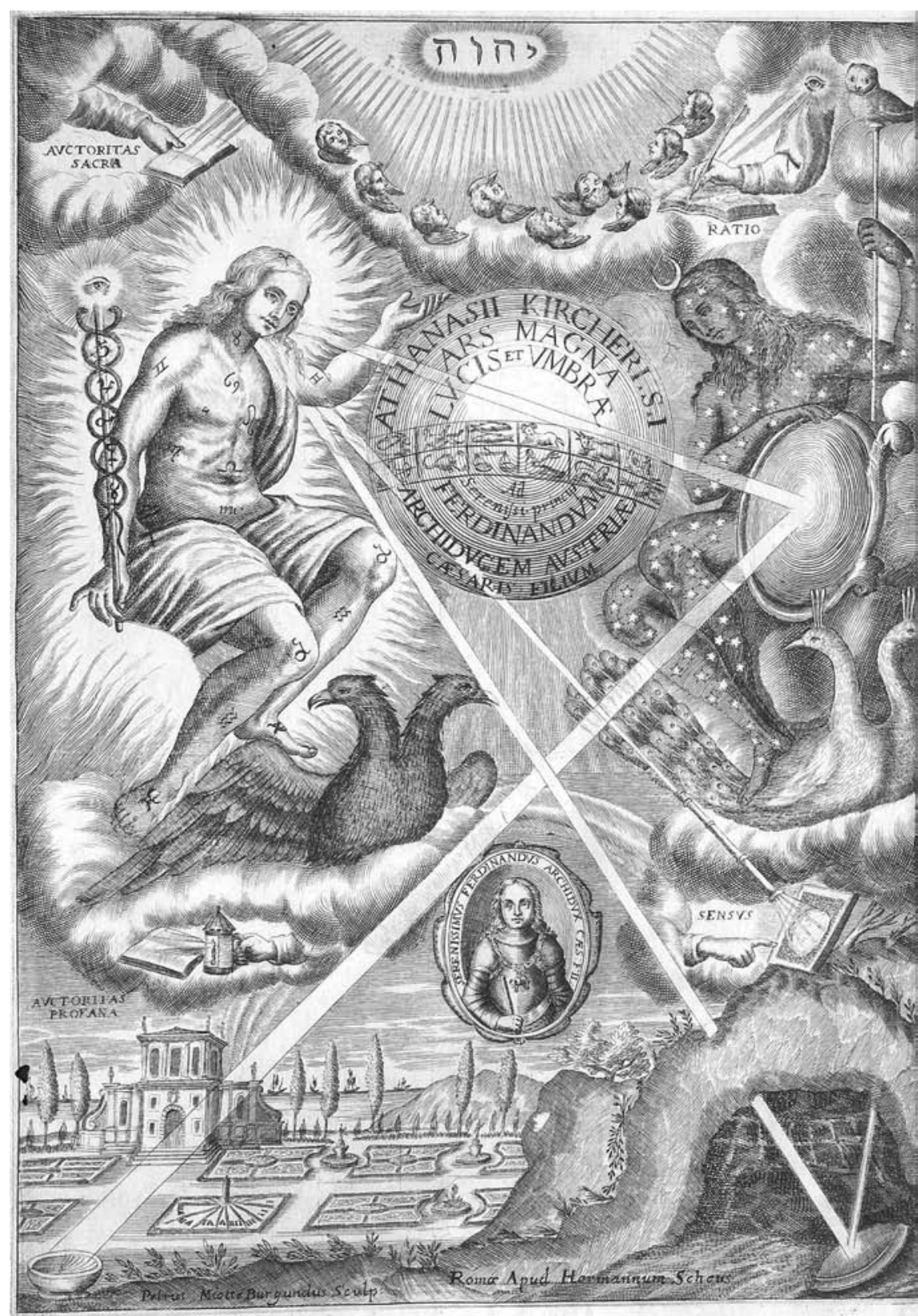

FIGURE 2 Pierre Miotte, frontispiece to Athanasius Kircher, Ars magna lucis et umbrae (Roma: Scheus, 1646) (Photo: commons.wikimedia.org; photograph in public domain) 
jasper, porphyry and other precious materials of different colours whose splendour makes the garden very beautiful. ${ }^{14}$

De Serres' observation is important because it points to the possibility that many such gnomon-shaped objects may at some point have been used as part of a garden sundial.

A floral meridian, similar to the one depicted on Bettini's and Kircher's frontispieces, existed at the Villa Aldobrandini at Frascati (1601-1605; 1613-1614) designed by Giacomo della Porta and Carlo Maderno for Cardinal Pietro Aldobrandini, nephew of Pope Clement VIII (r. 1592-1605). The sundial is visible in Dominique Barrière's view of the villa (1647) and described in the legend (4) as an "horologia è myrto," a sundial made of myrtle (Figs. 3a and 3 b). This plant had prestigious symbolic associations and was almost as precious as the orange tree. ${ }^{15}$ Significantly, it produces star-shaped flowers, making it an appropriate fabric for a sundial. The sundial is already visible in Matthias Greuter's panoramic view of Frascati engraved in 1620 (Figs. $4 \mathrm{a}$ and $4 \mathrm{~b}$ ), but it is not mentioned in the relatione, or description of the villa, dated ca. 1611 and attributed by Cesare D'Onofrio to the cardinal's maggiordomo and segretario Monsignor Giovanni Battista Agucchi. ${ }^{16}$ As we know from a letter to Cardinal Pietro Aldobrandini, dated 1620-1621, now in the Vatican Library, Agucchi served as adviser

14 "Aucuns, au milieu \& aux angles des Compartiments plantent des arbrisseaux sursaillans en haut, en quoy ils se trompent, car cuidans [sic] donner grace au Compartiment, ils en obfusquent le lustre par telles couvertures. Si toutefois l'on y en désire, y seront plantez les arbres les moins fueilleuz, \& dont le tige monte hautement \& droitement: comme le cyprez, par dessus tout autre à ce service estant le plus propre, \& convenablement est posé pour esguille au centre d'un cadran dressé en herbage au parterre marquant les heures. Au lieu des arbres pourra-on appliquer quelques rares antiquitez, Statuës, Colomnes, Pyramides, Obelisques \& semblables pièces de marbre, jaspe, porphire \& d'autres précieuses matières de diverses couleurs dont la richesse rend le Iardin tres magnifique," Olivier de Serres, Le Théâtre d'Agriculture et Mesnage des Champs (Paris: Jamet Metayer, 1600), pp. 530-531.

15 Mirella Levi D'Ancona, The Garden of the Renaissance: Botanical Symbolism in Italian Painting (Firenze: Olschki, 1977), pp. 237-241 (n. 108).

16 Relatione della Villa Belvedere is in Frascati, Archivio Aldobrandini, fondo "Villa Belvedere," vol. XII, fasc. 6, cc. $1-7,10-10^{\mathrm{v}}, 15^{\mathrm{v}}-27$. See Cesare D’Onofrio, La Villa Aldobrandini di Frascati (Roma: Staderini, 1963), pp. 82-115. On the villa, see also Klaus Schwager, "Kardinal Pietro Aldobrandinis Villa di Belvedere in Frascati," Römisches Jahrbuch für Kunstgeschichte, 1962, 9/10:291-382, and Marcello Fagiolo, "Villa Aldobrandini Tusculana: percorso, allegoria, capricci," Quaderni dell'Istituto di Storia dell'Architettura, 1964, 11, 62/66:6192. 


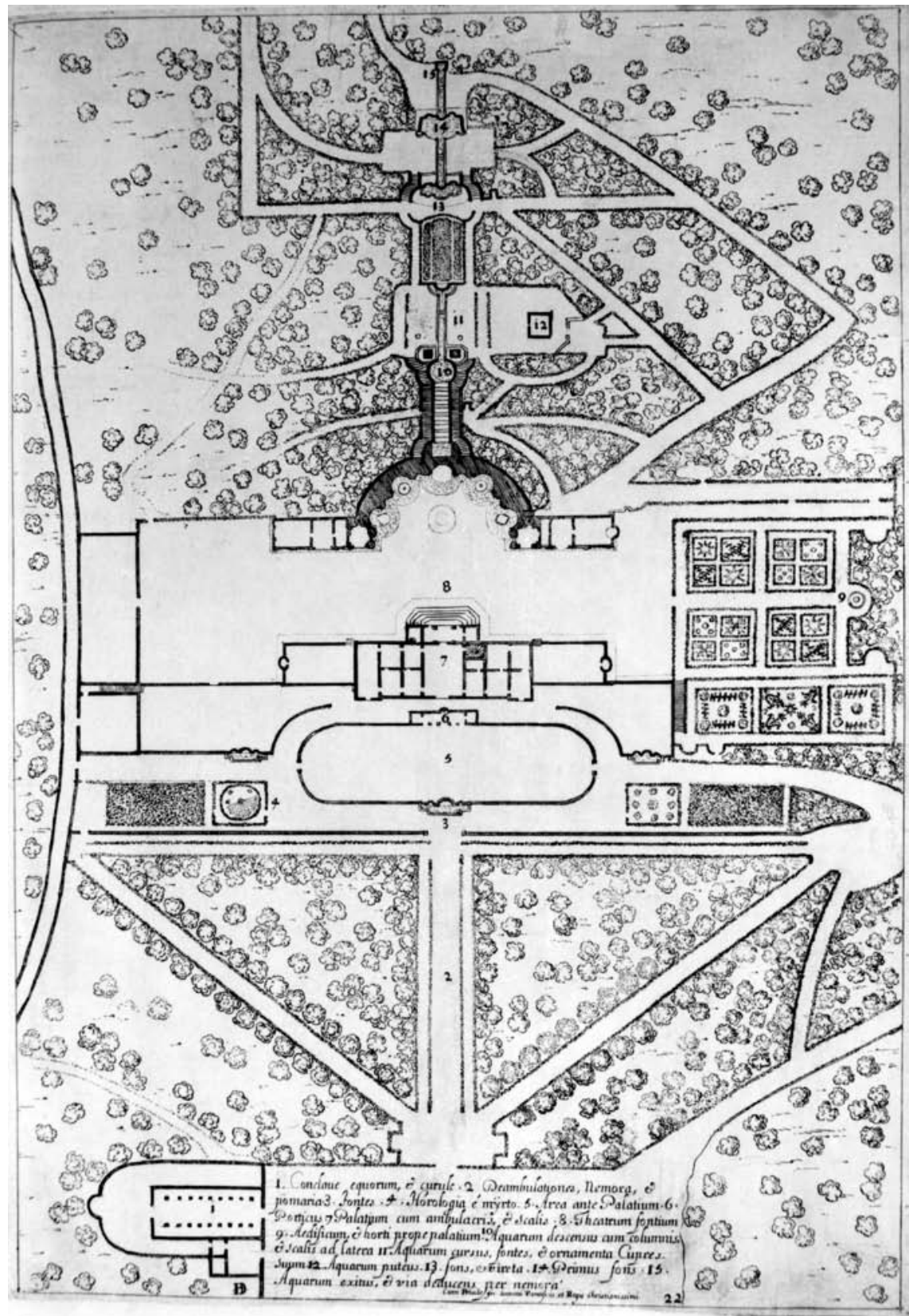

FIGURE 3A Dominique Barrière, Plan of the Villa Belvedere and its gardens, from Villa

Aldobrandina Tusculana sive varii illius hortorum et frontium prospectus (Roma, 1647), p. 22; etching (Photo: Bibliotheca Hertziana) 

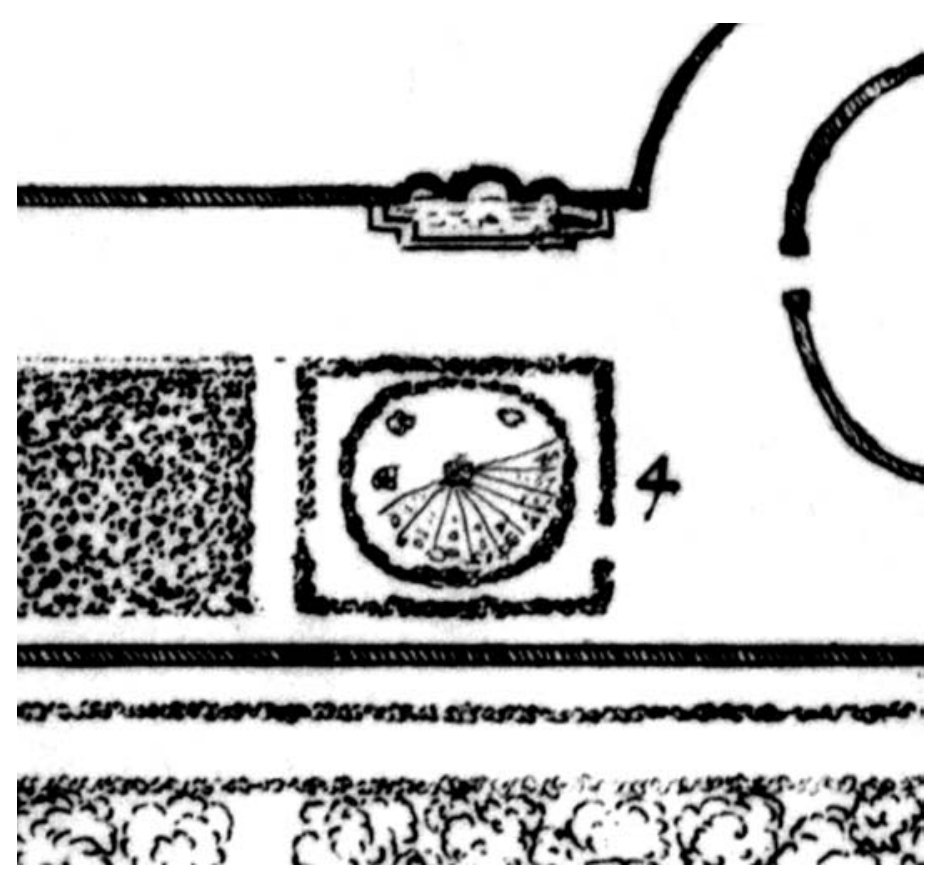

FIGURE 3B Detail of the sundial

for the programme of the famous Teatro d'Acqua, the water theatre behind the villa, facing the garden façade (Fig. 5) $\cdot{ }^{17} \mathrm{He}$ also most likely conceived the Stanza dei Venti or Sala d'Apollo, which was finished in the spring of 1619, with its extraordinary hydraulic instruments and its vault painted in imitation of an aviary (Fig. 6).

The sundial at the Villa Aldobrandini was set in a conspicuous position in front of one of the two rustic fountains that flanked the great hippodrome. As in Kircher's ideal garden, the circular quadrant of the sundial was enclosed within a large square compartment. It was monumental, a small garden in itself, if we compare its size on the plan with that of the rustic fountain set immediately behind. We may note that the sundial depicted by Barrière is not exactly similar to the one in Greuter's engraving and that it is located on the other side of the hippodrome. Although there is a possibility that it is not the same sundial, I believe Barrière simply placed it on the wrong side when copying the engraving by Greuter. Not only must the sundial have attracted the

17 This letter is preserved in the Biblioteca Apostolica Vaticana, Cod. Ottob. Lat 3255, cc. $328 \mathrm{ff}$. See D’Onofrio, La Villa (cit. note 16), pp. 121-122. 


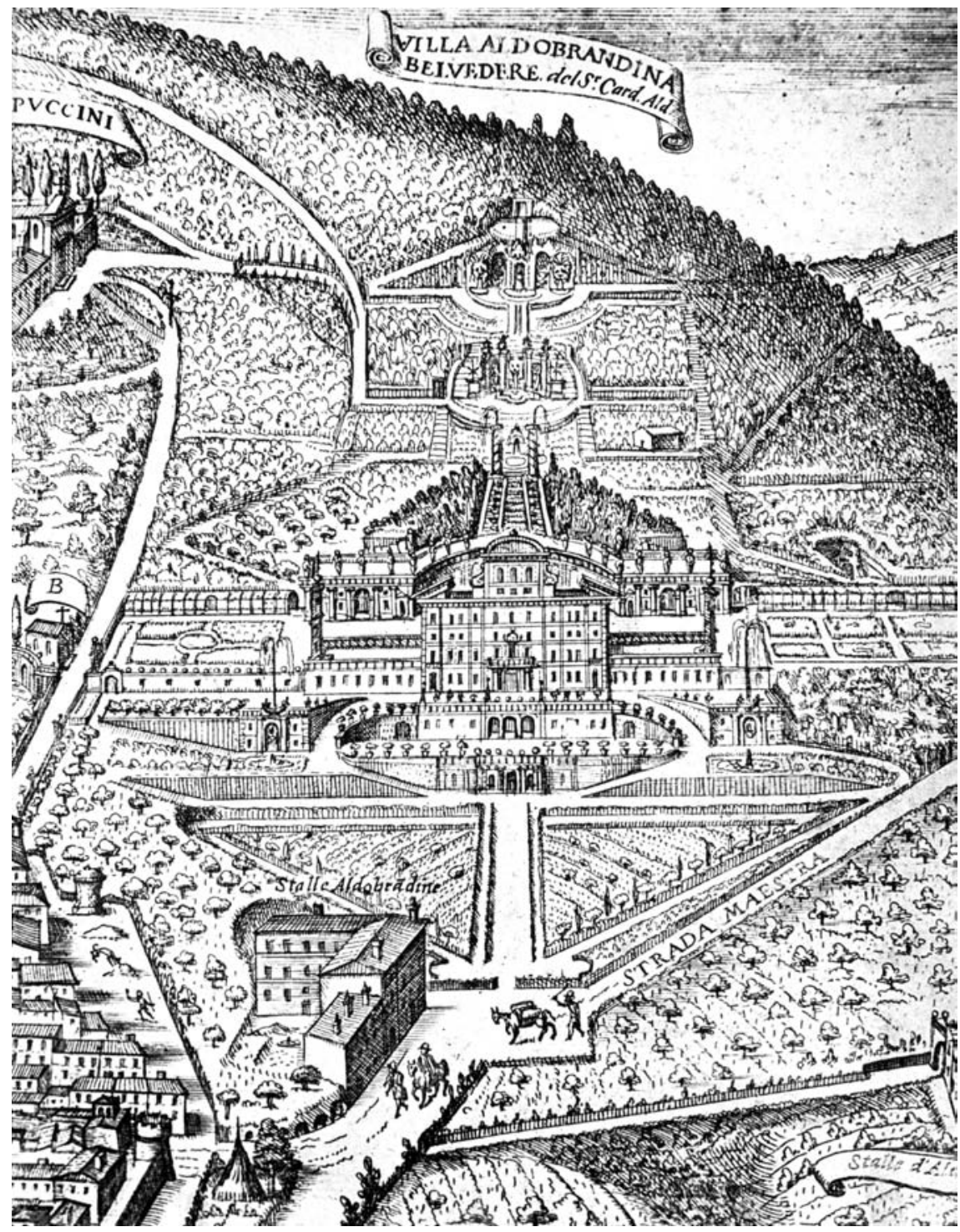

FIGURE 4A Matthias Greuter, Frascati. Disegnato e dato in luce da M. Greuter (Roma, 1620), engraving, detail of the Villa Belvedere (Photo: Bibliotheca Hertziana) 


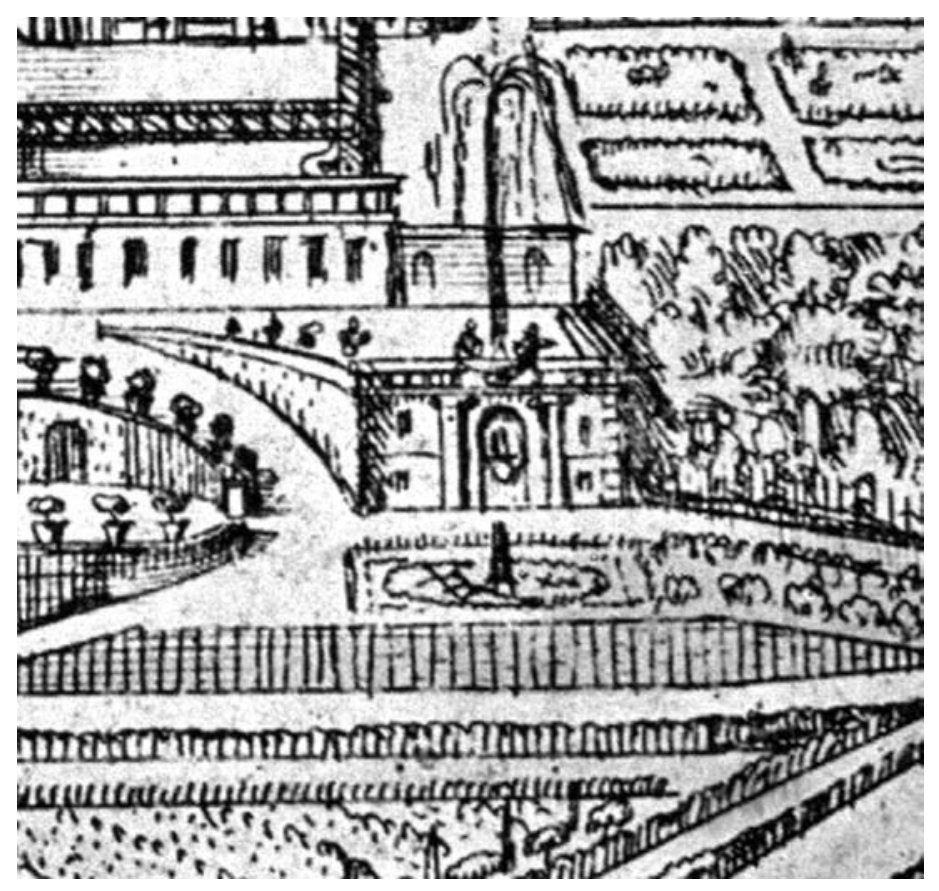

FIGURE 4B Detail of the sundial

attention of visitors walking up towards the villa, it also formed an exceptional viewing platform from which to admire the fabulous panorama of the Roman countryside, a panorama that Agucchi described as if it were a map rather than a landscape, stressing its territorial and cosmic dimensions. ${ }^{18}$ Since a sundial is always precisely oriented, it could well have played the role of a wind rose, helping visitors to situate geographically the localities they could see from this privileged vantage point. At that particular spot, time and space, cosmology and cosmography, the course of the sun across the sky and the magnificent landscape were all bound together in a unified vision. Cardinal Pietro himself, inspired by Pliny the Younger's description of the view from his villa as a "theatrum mundi" (Ep.v.6.7), aptly described this view as a "great theatre" made by God, "the architect of the world."19 In Agucchi's Relatione, the view is given an even more precise significance:

18 Ibid., pp. $87-89$.

19 Schwager, Kardinal Pietro (cit. note 16), pp. 300, 372; Ronald Martin Steinberg, "The Iconography of the Teatro dell'Acqua at the Villa Aldobrandini," The Art Bulletin, 1965, 47, 4:453463 , p. 455 . 


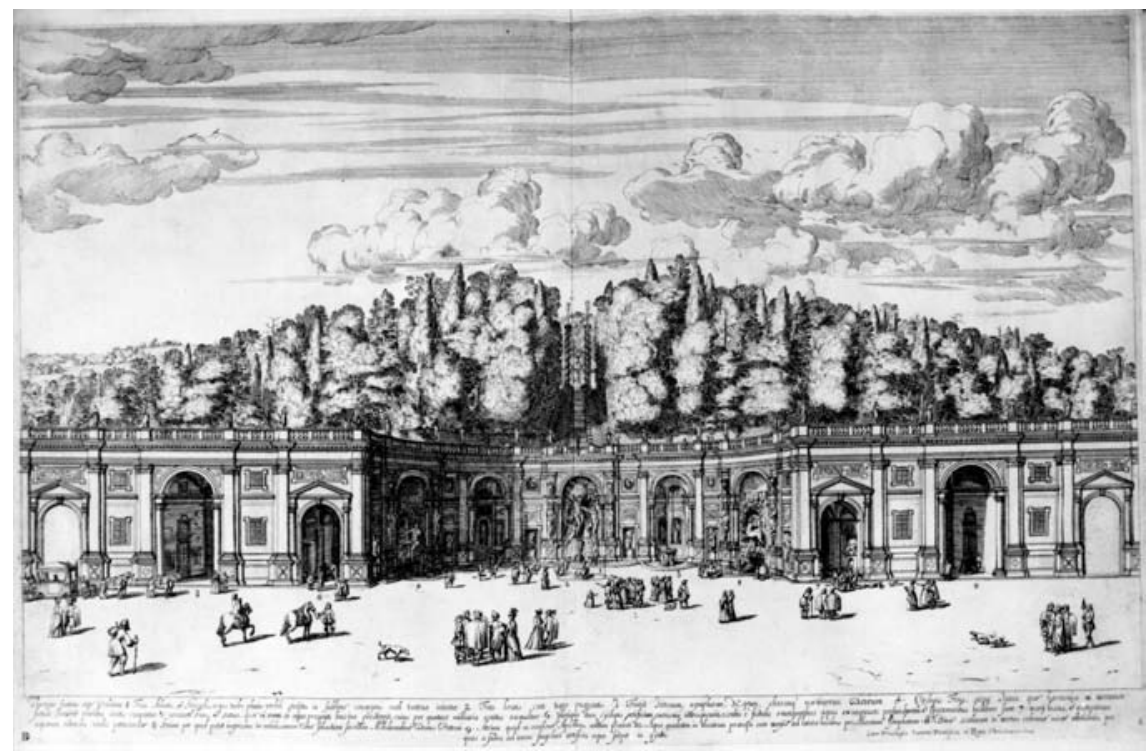

FIgURE 5A Dominique Barrière, Teatro d'Acqua, etching, 1647, from Villa Aldobrandina Tusculana, p. 6. (Photo: Bibliotheca Hertziana)

One sees in [this vista] the ancient and imperial city of Rome, master of nations, conqueror of the world and head of the true Religion. This, by itself, makes the view from Frascati and her villas unique. [One can scrutinise] her parts, and just as the head of the Church Militant dominates here [in Frascati], so does the material Church in the most noble edifice of St. Peter's rise up and dominate [Rome] as the first Church of the world, displaying for miles her very great and high cupola. ${ }^{20}$

The presence of the sundial near the hippodrome is directly linked with such an image of imperial power, in the same way that, set above the great rustic fountains, two smaller fountains in the form of barchette referred to the famous Navicella of Old St. Peter's. ${ }^{21}$ At the Villa Aldobrandini, the hippodrome recalled ancient Roman imperial models (notably the hippodrome of Pliny's

20 D'Onofrio, La Villa (cit. note 16), pp. 87-89. I quote the English translation given in Tracy Ehrlich, Landscape and Identity in Early Modern Rome. Villa Culture at Frascati in the Borghese Era (Cambridge: Cambridge University Press, 2002), p. 84.

21 See Anatole Tchikine, "Galera, Navicella, Barcaccia? Bernini's Fountain in Piazza di Spagna Revisited," Studies in the History of Gardens \& Designed Landscapes: An International Quarterly, 2011, 31, 4:311-331, pp. 318-320. 


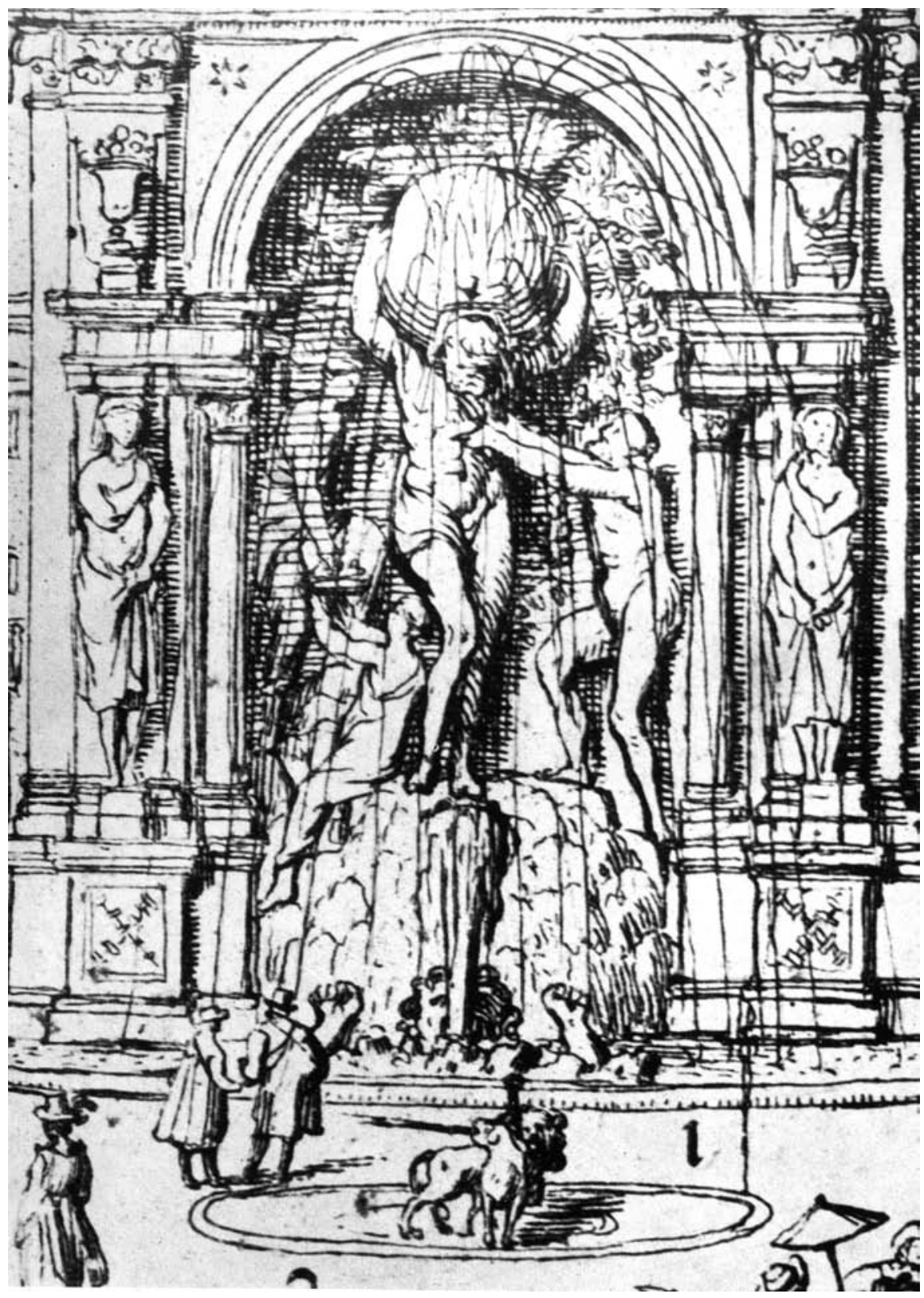

FIGURE 5B Detail of Atlas and Hercules 


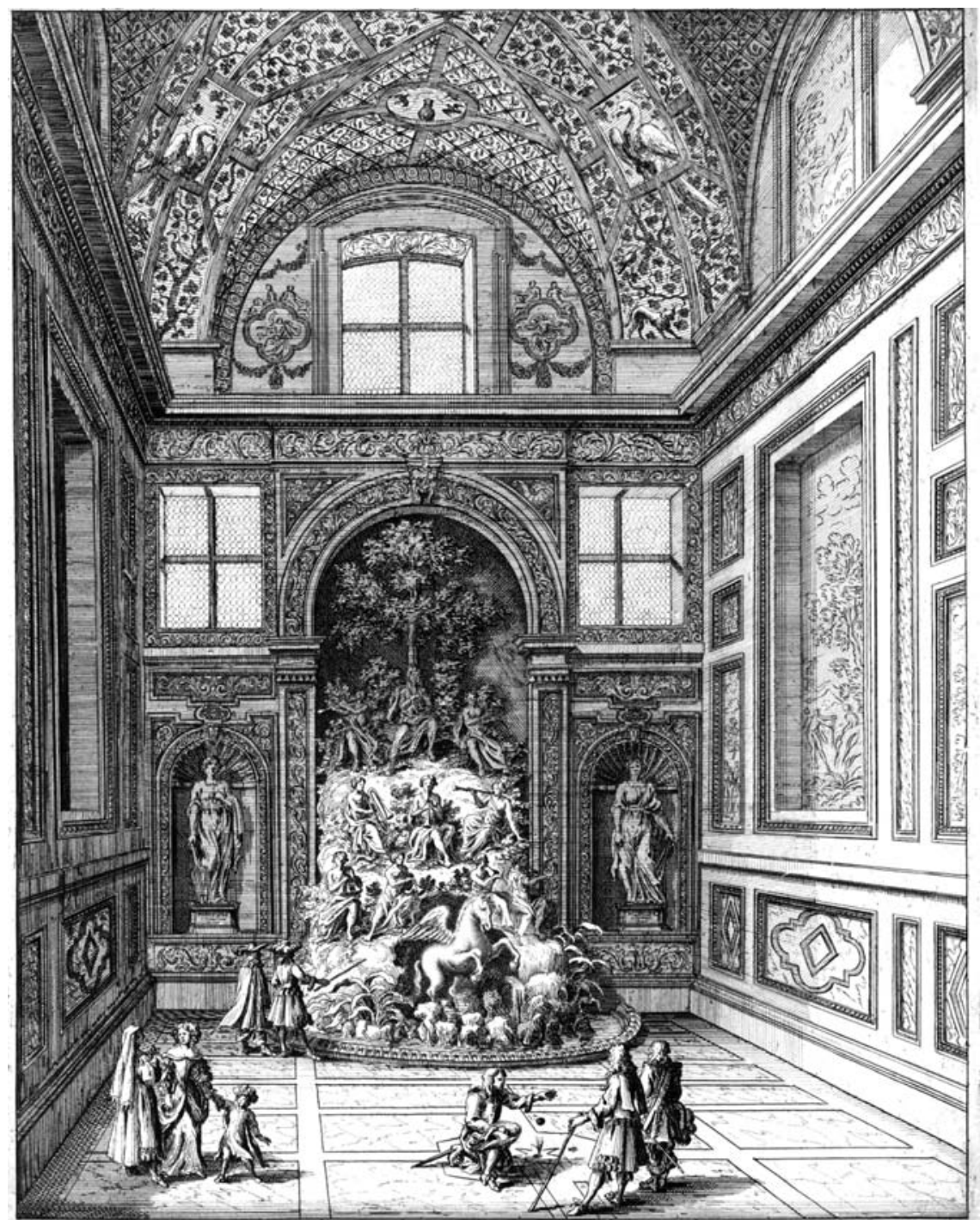

$S$ TANZA DE VENTI NEL TEATRO DI BELVEDERE DI FRASCATI CON LA FAMOSA FONTANA DEL. MONTE PARNASO CON APOLLINE ET LE MVSE CHE SVONANO CON INSTRVMENTT HIDRAVICI A FORZA D' ACOVA ARCHITETTVRA DI GIACOMO DELLA PORTA.

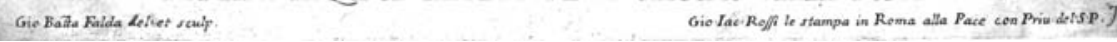

FIGU RE 6 Giovanni Battista Falda, published by Giovanni Giacomo de' Rossi, Stanza de Venti, Fountain of Mount Parnassus in the theatre of Belvedere in Frascati, etching, ca. 1665-1691, 318×235 mm, London, British Museum (1928,0713.8) (Photo: Trustees of the British Museum) 
villa and the great circus maximus), where games dedicated to the Sun were held. Shaped like an obelisk, the sundial's gnomon probably alluded to the famous horologium Augusti, a monumental sundial well known to Renaissance antiquarians, set in the ancient Campus Martius. ${ }^{22}$ In a long poem on the villa published in 1648, Giovanni Battista Ciampoli (1589-1643), Galileo's friend and perhaps his most ardent supporter at the Roman court, mentions the sundial, giving ample confirmation of this reading:

Clio, sì lungo soggiorno

Far non conviensi in un oggetto istesso.

Vivo horologio in verdi bossi espresso

T'addita l'hore del volubil giorno.

Veggio line frondose

A fronzuto obelisco estese intorno.

Oh con qual norma il Sole

Misurar l'ombre suole

In quel verde confin d'herbe ingegnose!

Nè l'Egittia Piramide ad Augusto

Segnò nel Martio campo il dì sì giusto. ${ }^{23}$

Ciampoli moved to Rome from Florence in 1614 and frequently accompanied the cardinal to Frascati from then on. Letters were sent to Galileo from Frascati in 1618 and 1619, as will be seen below. It is thus reasonable to assume that the sundial was already built in those years.

In Barrière's engraving, the garden's parterres are designed in the shape of the Aldobrandini coat of arms, featuring stars and rastrelli, rakes or battlements (Fig. 3). The myrtle sundial, with its star-shaped flowers, logically entered into

22 On the solar and cosmic symbolism of ancient Roman hippodromes in Baroque culture, see Marcello Fagiolo, Roma barocca. I protagonisti, gli spazi urbani, i grandi temi (Roma: De Luca, 2013), pp. 116-120 and note 21, p. 125. On Augustus' sundial, see Pliny, Natural History, xxxvi, 70-73; Cesare d'Onofrio, Gli obelischi di Roma (Roma: Bulzoni, 1965), pp. 280-291.

23 "Oh Clio, it is unworthy to spend so much time on the same subject. The living dial expressed in green boxwood indicates the hours of the revolving day. I see leafy lines spread around a verdant obelisk. Oh, with what rule the Sun measures the shadows in such green confines [made] of ingenious grass! Not even the Egyptian pyramid dedicated to Augustus in the Field of Mars marked [the hours of] the day so justly," Giovanni Battista Ciampoli, Rime di Monsignor Giovanni Ciampoli ... (Roma: Corbelletti, 1648), pp. 54-72, p. 66. On Ciampoli, see note 89 below. 
this heraldic design, like other astronomical inventions dedicated to Cardinal Aldobrandini, for instance a perpetual calendar by Ortensio Toro of 1594 decorated with stars (Fig. 7). ${ }^{24}$ In his letter to Pietro Aldobrandini regarding the Teatro d'Acqua, in which he suggested the subject of Atlas or Hercules supporting a celestial globe, Agucchi also noted how well this iconography fitted with the cardinal's heraldic devices: "And first of all, no one can make better use of the celestial orb than the Aldobrandini, because the emblem on their coat of arms seems to imitate the celestial circle with [its] degrees, and with the stars around. [...] All of these features very well suit our site, our water and our endeavour ..." ${ }^{25}$ Several globes with stars, closely resembling ancient Roman zodiacal spheres, still decorate the garden at Frascati and the hanging garden of the Villa Aldobrandini at Magnanapoli, with its beautiful views of the city of Rome. It is indicative of the strong connection between the figures of Atlas and Hercules and astronomy that we should often find statues of those heroes holding the celestial sphere serving as clocks or sundials. Joseph Moxon, a member of the Royal Society, illustrated his treatise on astronomy of 1659 with one such figural sundial, which stood in the garden of Robert Titchborn, Lord Mayor of London, in 1657. David Coffin suggested, as a source, the famous ancient statue known as the "Farnese Atlas." ${ }^{26}$ However, the statue more closely resembles Jacques Sarrazin's great Atlas at the Villa Aldobrandini.

Beside the omnipresent stars of the Aldobrandini's arms, other features of the Villa Belvedere evoked the dual world of astronomy and cosmography. Facing the Teatro d'Acqua and corresponding to the two Herculean columns at the head of the cascading 'water chain' (a well-known image of the limits of the world), ${ }^{27}$ the projecting central part of the garden façade is decorated with the Aldobrandini sun at its summit (Fig. 8). Marcello Fagiolo has called this avant-corps a "tower-observatory," since it recalls, with its three superimposed

24 Ortensio Toro, Rota Perpetua per trovar a quant hore si leva il sole e quando e mezzo giorno, 1594, $47.2 \times 39.5 \mathrm{~cm}$, engraving, published by Nicolas van Aelst and Giovanni Battista de Rossi, New York, Cooper Hewitt Museum, inv. 1963-9-317.

25 "E prima, niuno può usare meglio l'orbe celeste che gli Aldobrandini perché l'impresa dell'arme loro pare che imiti un cerchio celeste co' gradi, e con le stelle intorno. [...] Tutti questi accorgimenti convengono ottimamente al nostro sito, alla nostr'acqua et alla nostra impresa ...," D'Onofrio, La Villa (cit. note 16), pp. 121-122.

26 Joseph Moxon, A Tutor to Astronomy and Geography (London, 1659). See David Coffin, The English Garden. Meditation and Memorial (Princeton: Princeton University Press, 1994), fig. 6, pp. 20-21.

27 On the columns of Hercules, see Steinberg, "The Iconography of the Teatro" (cit. note 19), pp. 456-457. 


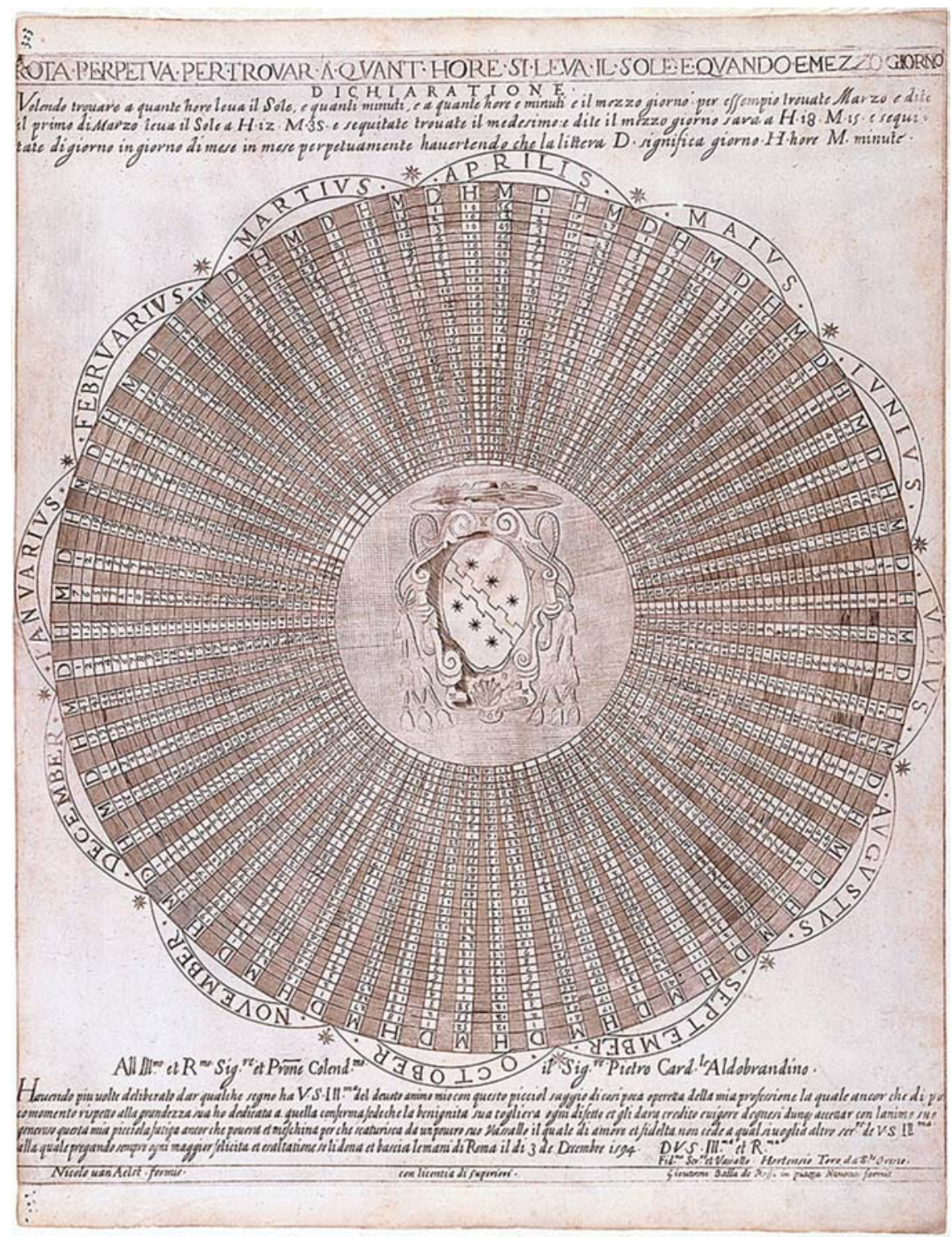

FIGURE 7 Ortensio Toro, published by Nicolo Van Aelst and Giovanni Battista de' Rossi, Rota perpetua per trovar a quant hore si leva il sole e quando e mezzo giorno, 1594, engraving, $47.2 \times 39.5 \mathrm{~cm}$, New York, Cooper-Hewitt Museum (1963-9-317) (Photo: Cooper-Hewitt Museum)

NUNCIUS $30(2015)$ 124-160 


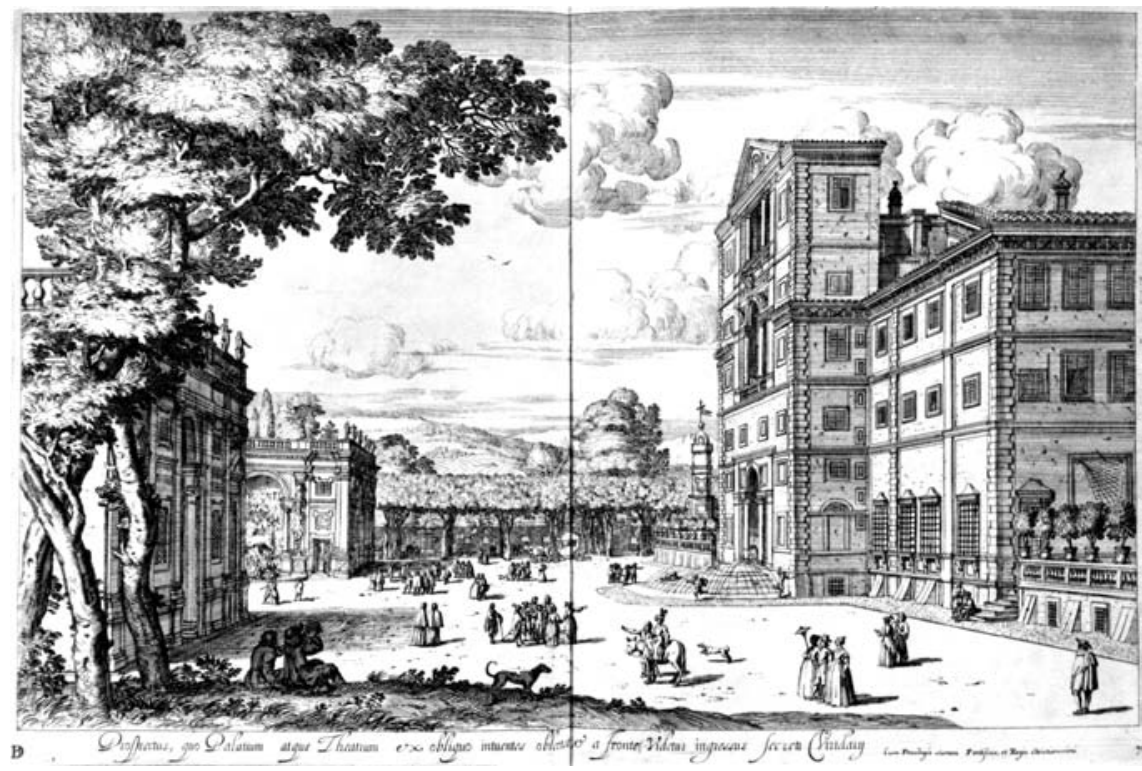

FIGURE 8 Dominique Barrière, Side view of the water theatre, etching, 1647, from Villa Aldobrandina Tusculana, p. 7 (Photo: Bibliotheca Hertziana)

loggias, the architecture of astronomical towers. ${ }^{28}$ Furthermore, a very large vertical rectangular sundial was set into the wall on the eastern side of the villa, overlooking the giardino segreto, where rare plants were grown. It figures prominently in another print by Barrière (1647), probably slightly exaggerated in size (Fig. 8). A drawing by Israël Sylvestre depicts it in more reasonable dimensions. ${ }^{29}$

\section{Scientific Curiosity and the Culture of Wonder}

In Renaissance gardens, fountains and statues were part of larger ensembles with a more or less determined meaning. Often these artefacts were disposed within the space of the garden to create a narrative for the promenading visitors. Thus, we may reasonably assume that the sundials at the Villa Belvedere were not perceived as isolated objects but were seen as part of an integrated whole.

28 Fagiolo, Villa Aldobrandini (cit. note 16), p. 95. On the function of this "viewing tower," see also Ehrlich, Landscape and Identity (cit. note 20), p. 101.

29 Schwager, Kardinal Pietro (cit. note 16), plates 249 and 250, pp. 298-299. 
Like the complex mechanisms of fountains, sundials were "marvellous" machines. To be understood, they required mathematical knowledge. Already in antiquity, Vitruvius had dedicated an entire chapter to gnomons and sundials in his treatise on architecture, which in addition contained instructions for making hydraulic machines (De architectura, IX). During the Renaissance, many students of optics and astronomy who wrote about sundials also published studies on pneumatics and hydraulics. For example, Federico Commandino and his student Bernardino Baldi have left us translations of Hero of Alexandria's Pneumatics, a work that had a strong impact on famous Italian Renaissance gardens, ${ }^{30}$ while also producing treatises on gnomonics. ${ }^{31}$ In the garden, astronomical, pneumatic and hydraulic instruments were meant to advance knowledge of the world and to provoke wonder, whilst celebrating the owner of the garden for his ability to rule over untamed nature. Water channels and fountains disciplined the natural streams descending from mountains, underground sources and rivers, whilst sundials or other astronomical devices, as models of the universe, made the movements of the heavens legible. In De cardinalatu, published in 1510, Paolo Cortesi explained that mathematical instruments (such as dials, clepsydrae or water pumps) were suitable subjects for the painted decoration of garden rooms in a cardinal's palace, being a stimulus for both the imagination and the intellect:

The more subtle a mathematical concept [subtilior mathematica ratio] a painting displays, the more learned [litteratior] the picture will appear. For instance, there could be a painting something like a hydraulic or Ctesibian machine the representation of which permits more subtle reasoning [by the viewer]. And likewise there is no less delight to the learned in a painted picture of the world or the depiction of its parts [...]. And the same holds true for paintings done from life [zoographiae describendae ratio $]^{32}$

30 See Matteo Valleriani, "Il ruolo della pneumatica antica durante il Rinascimento:l'esempio dell'organo idraulico nel giardino di Pratolino," in La civiltà delle acque, edited by Arturo Calzona and Daniela Lamberini, 2 vols., Vol. II (Firenze: Olschki, 2010), pp. 613-632.

31 Federico Commandino, Horologiorum descriptio (Roma, 1562); Bernardino Baldi, Novae gnomonices libri quinque (Guastalla, 1592).

$3^{2}$ John F. D'Amico and Kathleen Weil-Garris, "The Renaissance cardinal's ideal palace: a chapter from Paolo Cortesi's De cardinalatu," in Studies in Italian Art History, 1 (Memoirs of the American Academy in Rome, 35), (Roma, 1980), pp. 94-97.

NUNCIUS $30(2015) 124-160$ 
Thus, at the Villa Aldobrandini, the sundials (gnomonics) were linked not only to the rare plants and flowers in the secret garden (botany), but also with the already-mentioned Stanza dei Venti (hydraulics) adorned with a great variety of birds and other small animals (natural history). We can also compare the sundials and other artefacts in the garden on the basis of their iconography. For instance, in the Stanza dei Venti, Apollo is represented on Parnassus surrounded by the Muses and Pegasus, representing the triumph of art and science, but also a figure associated with the Sun. In this room, music was produced through particularly complex hydraulic organs shaped like wind instruments held by wooden figures, which provoked wonder among the visitors. ${ }^{33}$ In the middle of the floor, a hole had been made through which a jet of fresh air was blown, enabling a metal ball to be held suspended in mid-air (Fig. 6). Later visitors described more than one such mechanism.

Athanasius Kircher and his fellow Jesuit Gaspar Schott not surprisingly praised the Stanza dei Venti and its hydraulic mechanisms in their books. In the catalogue of Kircher's famous Musaeum in Rome, besides "many sundials," similar devices were described, such as an "organ, driven by an automatic drum, playing a concert of every kind of birdsong, and sustaining in mid-air a spherical globe, continually buffeted by the force of the wind," and "a little fountain moving the globe weighing down on the head of Atlas in a circle by hidden movements." ${ }^{34}$ Schott dedicates many pages to the Villa Aldobrandini in his Mecanica hydraulico-pneumatica of 1657 , mentioning sundials among the marvellous inventions to be found in Roman gardens. ${ }^{35}$ At the Villa Belvedere, he noticed the frightening sound made by the Atlas and Hercules fountain, imitating thunder as if a storm were about to break. ${ }^{36}$ Many travellers after him mentioned it as well. The English virtuoso and cognoscente John Evelyn, visiting the villa on 5 May 1645 , marvelled at the "exact and perfect rainbow" appearing above the sculptural group when the sun was shining, and the

33 Patrizio Barbieri, “Organi idraulici e statue 'che suonano' delle ville Aldobrandini (Frascati) e Pamphilj (Roma). Monte Parnaso, Ciclope, Centauro e Fauno," L'organo. Rivista di cultura organaria e organistica, 2001, 34:5-175.

34 Georgius de Sepibus, Romani Collegii Musaeum Celeberrimum (Amsterdam: Ex Officina Janssonio-Waesbergiana, 1678). See Michael John Gorman, "Between the Demonic and the Miraculous: Athanasius Kircher and the Baroque Culture of Machines," in The Great Art of Knowing: The Baroque Encyclopedia of Athanasius Kircher, edited by Daniel Stolzenberg (Stanford: Stanford University Libraries, 2001), pp. 59-70, pp. 59-6o.

35 Gaspar Schott, Mechanica Hydraulico-Pneumatica (Würzburg, 1657), pp. 325-328; Id., Magia universalis natura et artis, Vol. II (Bamberg, 1674), p. 329.

36 Schott, Mechanica (cit. note 35), p. 326. 
impressive height of the jet of water gushing out from the giant Enceladus' mouth:

Just behind the Palace (which is of excellent architecture) in the centre of the inclosure, rises a high hill, or mountain, all over clad with tall wood, and so formed by nature, as if it had been cut out by art, from the summit whereof falls a cascade, seeming rather a great river than a stream precipitating into a large theatre of water, representing an exact and perfect rainbow, when the sun shines out. Under this, is made an artificial grot, wherein are curious rocks, hydraulics organs, and all sorts of singing birds, moving and chirping by force of the water, with several other pageants and surprising inventions. In the centre of one of these rooms, rises a copper ball that continually dances about three feet above the pavement, by virtue of a wind conveyed secretly to a hole beneath it; with many other devices to wet the unwary spectators, so that one can hardly step without wetting to the skin. In one of these theatres of water, is an Atlas spouting up the stream to a very great height; and another monster makes a terrible roaring with a horn; but, above all, the representation of a storm is most natural, with such fury of rain, wind, and thunder, as one would imagine oneself in some extreme tempest. ${ }^{37}$

Like most visitors, Evelyn insists on the play between art and nature. However, his comments also reveal a specific interest not only in the artialisation (to use Alain Roger's term, borrowed from Montaigne) of nature as it appears when fixed and immobile, but also in the representation of the movement, the mutability, the ever-changing aspect of nature. Rushing streams, splashing water, rainbows, wind, terrific sound and gentle music, tempest, sunlight, and so forth: these elements are in constant movement and interaction with one another. Thus, it is not through their intellects, detached as it were from the senses, that visitors could appreciate these "surprising inventions," but through an act of thinking compelled by moving, seeing, smelling, hearing and touching. This describes not only an important difference in the history of garden design between the Renaissance and the Baroque, but also a major epistemological shift in the history of science. Both Galileo and a wide circle of so-called natural philosophers were, at the very moment when the Villa Aldobrandini was receiving its first visitors, increasingly detaching themselves from a strict

37 William Bray (ed.), Diary and Correspondence of John Evelyn, Vol. 1 (London: George Bell and Sons, 1878), pp. 185-186.

NUNCIUS $30(2015) 124-160$ 
adherence to ancient authorities, among whom the most prominent was Aristotle. Instead, they favoured a scientific method that conferred unprecedented importance on sensory experience, whereby theories and hypotheses had to be verified against direct observations of the natural world. ${ }^{38}$

These thinkers and the gracious and cultivated surroundings in which they lived in Italy made a profound mark on John Evelyn. Upon his return to England he embarked on the writing of his monumental work on gardens, Elysium Britannicum, in which he attempted to devise what could be called a philosophy of gardens, dwelling on "how the aire and genious of Gardens operat upon humane spirits towards virtue and sanctitie." ${ }^{39}$ Later, he would create a "natural philosopher's garden" at Albury Park, clearly inspired - both in design and in spirit - by the Villa Aldobrandini, which he had visited in $1645 .{ }^{40}$

Indeed, the members of the Aldobrandini family themselves were intellectually inclined towards the study of natural philosophy. The pope, Ippolito, had studied at Padua, inviting one of his former professors, the philosopher Francesco Patrizi, to take a chair at the Sapienza in Rome in 1592. It is said of Patrizi's "New Philosophy" that "it provided a major alternative to earlier schools of thought and a model which later thinkers such as Galileo Galilei no doubt found valuable in developing the mathematized physics which would prove the dominant force in the rise of early modern science."11 Pietro's cousin, Cardinal Cinzio Aldobrandini, was an important advocate of such interests. ${ }^{42}$

38 Stillman Drake, "Galileo on Sense Experience and Foundations of Physics," Isis, 1977, 68, 1:108-110, p. 108.

39 For the quote, see the letter to Sir Thomas Browne dated 28 January 1658 in Thomas Browne, The Letters of Sir Thomas Browne, edited by Geoffrey Keynes (Cambridge, Cambridge University Press, 1946) pp. 300-302. On John Evelyn as a natural philosopher, see Michael Hunter, "John Evelyn in the 1650s: A Virtuoso in Quest of a Role," in John Evelyn's "Elysium Britannicum" and European Gardening, edited by Therese O' Malley and Joachim Wolschke-Bulmahn (Washington: Dumbarton Oaks Research Library and Collection, 1998), pp. 79-106, p. 104.

40 On the influence of the Villa Aldobrandini on Evelyn's design of Albury Park, see Michael Charlesworth, "A Plan by John Evelyn for Henry Howard's Garden at Albury Park, Surrey," in John Evelyn's “Elysium Britannicum" and European Gardening (cit. note 39), pp. 289-293, p. 291. On the influence of Italian gardens on Evelyn's designs for English gardens, see John Dixon Hunt, Garden and Grove: The Italian Renaissance Garden in the English Imagination, 1600-1750 (Princeton: Princeton University Press, 1986), pp. 145-153.

41 See Fred Purnell, "Francesco Patrizi," in The Stanford Encyclopedia of Philosophy, Fall 2008 edition, edited by Edward N. Zalta, at http://plato.stanford.edu/archives/fall20o8/entries/ patrizi/ (accessed 13 June 2014).

42 Clovis Whitfield, “The 'camerino' of Cardinal Del Monte," Paragone. Arte, 2008, 59, 3:3-38, 
As for Pietro Aldobrandini, he was close to intellectual figures deeply interested in astronomy and science. Among them, we may recall Giulio Cesare Lagalla, "still halfway between Aristotelianism and the new natural philosophy," who would become Pietro's personal doctor, ${ }^{43}$ and Luca Valerio, one of the most important mathematicians of his time. Both were close to the Accademia dei Lincei and to Giovanni Battista Agucchi. ${ }^{44}$

Galileo was then at the centre of everyone's attention and friendly letters were exchanged between him and the cardinal. In a letter sent on 23 June 1612, Aldobrandini thanks Galileo for sending him one of his works, which he praises with enthusiasm. ${ }^{45}$ Poems celebrating Galileo's discoveries were dedicated to the cardinal, such as a work by Vincenzo Figliucci, Stanze sopra le nuove stelle scoperte col nuovo occhiale, published under the pseudonym Lorenzo Salvi in $1615 .{ }^{46}$ On 23 July 1618, Giovanni Ciampoli writes to Galileo from the Villa Aldobrandini at Frascati. He conveys the cardinal's best wishes and gladly reports to his friend how he is often the subject of conversations, provoking "not only praise but also admiration." He adds an interesting piece of information: "Your telescope entertained us a lot because of the beautiful views here; [the cardinal] was wondering if it would be possible to obtain through you an exemplar of special refinement, and he asked me to write to you about it." ${ }^{\prime 7}$ We may thus imagine the cardinal and his friends busily scanning the stupendous panorama with the new telescope and, at night, observing the stars. This is, in fact, confirmed by Ciampoli himself, who, praising the view in his poem on the villa, does not miss the opportunity of celebrating Galileo's telescope, calling it a "famous crystal":

p. 13. For an extensive discussion of cardinal Cinzio Aldobrandini's cultural and scientific interests, see Karen Lloyd, Adopted Papal Kin as Art Patrons in Early Modern Rome (15921676), Ph.D diss., Rutgers University, 2009.

43 On Lagalla, see Italo Gallo, "Filosofia e scienze negli albori del Seicento: Giulio Cesare Lagalla tra Aristotele e Galilei," Rassegna storica salernitana, 1986, 3:27-71.

44 See the letter of 2 August 1613 from Federico Cesi to Lagalla, mentioning Agucchi and Luca Valerio, in Giuseppe Gabrieli, Il carteggio linceo (Roma: Accademia Nazionale dei Lincei, 1996), p. 394. On Agucchi and Valerio, see Ugo Baldini and Pier Daniele Napolitani, "Per una biografia di Luca Valerio. Fonti edite e inedite per una ricostruzione della sua carriera scientifica," Bollettino di storia delle scienze matematiche, 1991, 11, 1:3-157.

45 Opere di Galileo Galilei (hereafter $O G$ ), edited by Antonio Favaro (Firenze: G. Barbèra, 1890-1909), Vol. XII, pp. 209-210.

46 See the letter of Luigi Maraffi to Galileo dated 12 December 1615 in $O G$, XII, p. 399.

$47 \quad O G$, XII, p. 465.

NUNCIUS 30 (2015) 124-160 
Oh quanto immenso [sic.] Anfiteatro giace!

Mira, ch' in lui s'allarga

Ben di cento Città spatio capace. [...]

Spettacolo giocondo

Quindi à legni drizzar del mare ondoso

Pregio di Galileo, cristal famoso,

Che nuove Stelle in Ciel scoperse al Mondo!48

No doubt the cupola of St. Peter's basilica, so conspicuously chosen as the focal point of the Aldobrandini panegyric in Agucchi's Relatione, was the main target in this game, in the same way that Galileo and his friends, gathered in the garden of Monsignor Malvasia on 14 April 1611, had tested the perfect efficacy of the telescope by checking the inscription over the door of the papal palace at San Giovanni in Laterano. ${ }^{49}$ When visiting the garden of the Villa Medici in Rome in 1604, Galileo's friend Lodovico Cigoli also naturally chose the cupola of St. Peter's as a focal point when experimenting with his new perspectograph..$^{50}$

It is important to remember that Pietro Aldobrandini, before acquiring the Villa Aldobrandini, had purchased and used, between 1597 and 1599, the famous 'alchemical' Casino of Cardinal Francesco Maria Del Monte on the Pincian Hill (Villa Ludovisi)..51 The knowledge of such a model of villeggiatura, explicitly dedicated to the study of the sciences and the marvels of nature, may well have had an impact on the way his villa at Frascati would later be conceived. Indeed, most revealing is John Evelyn's comparison of the Villa Aldo-

48 "Oh, how immense this amphitheatre is! Look, it is so wide that it can contain well over a hundred cities [...] Pleasing spectacle; then aiming at the ships [legni, poetic] on the wavy sea, the famous crystal, prize of Galileo, who revealed to the world new stars in the sky!" Ciampoli, Rime (cit. note 23), p. 68.

49 David Freedberg, The Eye of the Lynx: Galileo, His Friends, and the Beginnings of Modern Natural History (Chicago: University of Chicago Press, 2002), p. 108.

5o See Filippo Baldinucci, Notizie dei professori del disegno da Cimabue in qua [...], edited by Ferdinando Ranalli (Firenze: Studio per Edizioni Scelte, 1974-1975), v, p. 26o. I thank Filippo Camerota for this reference. See also two letters by Cigoli to Galileo: $O G$, XI, 666, on his telescopic observations of Frascati from Rome, and $O G$, XI, 573, where Giovanni Battista Agucchi's interest in telescopic observations is mentioned again.

$5^{1}$ Carla Benocci, Villa Ludovisi (Roma: Istituto Poligrafico e Zecca dello Stato, 2010), pp. 9596. On Cardinal Del Monte and his scientific interests, see Zygmunt Wazbinski, Il cardinale Francesco Maria del Monte (1549-1626) (Firenze: Olschki, 1994), pp. 409-491; on his contacts with Galileo, pp. 476-491. 
brandini with a Cabinet: "The Palace is indeede built more like a Cabinet, than any-thing compos'd of stone \& morter ..." ${ }^{\prime 2}$ In his view of the teatro, Dominique Barrière also refers to the fountains, tricks and other mechanical devices as "curiosities" (Fig. 5). In the rooms of the Casino Del Monte, besides a distilleria where the cardinal indulged in alchemical experimentation, many wonderful objects were on display: clocks, marble sculptures, mirrors, maps and musical instruments, which also made a strong impression on John Evelyn during his visit to the place in November $1644 .{ }^{53}$ These cabinets were directly connected with the space of the garden. The collector and connoisseur Cassiano Dal Pozzo mentions the presence of a sophisticated water clock in Cardinal Del Monte's garden on via di Ripetta. ${ }^{54}$ In the Del Monte inventory of 1622-1623, one also finds "dui occhiali da guardare lontano con la canna coperta di corame rosso dorato" - that is, telescopes. ${ }^{55}$

\section{3}

\section{The Meaning of the Atlas and Hercules Iconography}

In the light of the obvious recurrence of scientific and astronomical themes and objects at the Villa Aldobrandini, let us now reconsider the iconographic programme for the Teatro d'Acqua. The central group featured Atlas supporting the universe and Hercules reaching out for the globe (Figs. $5 \mathrm{a}$ and $5 \mathrm{~b}$ ). This has been interpreted in two different ways. In 1965 , Ronald Steinberg suggested a philosophical interpretation of the group. His reading, generally accepted by subsequent scholars, is convincing because it considers all the elements of the teatro and not just its central features. He writes:

$5^{2} \quad$ Diary and Correspondence ofJohn Evelyn (cit. note 37), p. 186.

53 On John Evelyn's appreciation of gardens and curiosity cabinets in Rome, see Hunt, “'Curiosities to Adorn Cabinets and Gardens'," in Garden and Grove (cit. note 40), pp. 73-82. Evelyn dedicates an entire chapter of his treatise on gardens to mechanical and hydraulic dials. See John Evelyn, Elysium Britannicum, or the Royal Gardens, edited by John Ingram (Philadelphia: University of Pennsylvania Press, 2001), pp. 245-252.

54 Cassiano Dal Pozzo, addendum to L. Pignoria, De Servis, et eorum apud veteres ministris, Augusta, 1613, p. 95. See Wazbinski, Il cardinale Francesco Maria del Monte (cit. note 51), p. 457: “[...] et a tempo mio per via d'acqua ho visto nel giardino della buona memoria del Card[ina]le del Monte un horiolo che mostrava e suonava le hore assai aggiustamente fabricato da Monsù di Manconine [...]."

55 Benocci, Villa Ludovisi (cit. note 51), pp. 438-445. Galileo gave one of his telescopes as a present to cardinal Cardinal Del Monte. See also Wazbinski, Il cardinale Francesco Maria del Monte (cit. note 51), pp. 477-478.

NUNCIUS 30 (2015) 124-160 
The action depicted in the Villa Aldobrandini Atlas and Hercules is traditionally interpreted as representing the astronomer, Atlas, teaching his science to Hercules, who, by acquiring the celestial sphere, which represents divine wisdom, becomes a philosopher, one who seeks divine wisdom [...] Since Hercules and Atlas are represented in the teatro in active juxtaposition, a meaning more complex than that implied by a static relationship, or by a depiction of Hercules alone, is suggested. More than a simple emblem of divine wisdom, the action of Hercules is the expression of both a positive and voluntary choice to seek divine wisdom. This visual embodiment of Hercules's desire corresponds precisely to the literary image employed by Giambattista Marino and Giambattista Guarini, who symbolised the virtues of Cardinal Aldobrandini in their poems by the figure of Hercules taking Atlas' heavenly sphere onto his shoulders. ${ }^{56}$

Steinberg refers here to poems associating Atlas with Clement viII and Hercules with Cardinal Pietro. Cesare D'Onofrio, who first published these poems, had proposed a political reading of the group, whereby Cardinal Pietro is seen in the act of lifting from his uncle's shoulders the burden of political affairs. The grouping together of Atlas (symbolising the pope) and Hercules (symbolising the cardinal, his nephew) had been used before by the Farnese family and was later taken up by the Borghese. D'Onofrio's nepotistic reading thus appears conclusive. ${ }^{57}$ To the literary evidence we can add an interesting and highly political print dating to ca. 1598 by Giovanni Luigi Valesio, associating the Aldobrandini family with Hercules holding the celestial sphere. ${ }^{58}$ It is also convincing because this kind of iconography appears in garden fountains as early as the sixteenth century, with clear political overtones. For instance, in 1551, a fountain was installed for Julius III in a small hanging garden at the Vatican. It probably represented Atlas holding the celestial sphere, framed by Hercules' columns: an image of the weight the pope was carrying on his shoulders. ${ }^{59} \mathrm{~A}$ medal associat-

56 Steinberg, "The Iconography of the Teatro" (cit. note 19), pp. 458-459.

57 Besides D’Onofrio, La villa (cit. note 16), pp. 122-123; Id., Roma vista da Roma (Roma: Ed. Liber, 1967), pp. 229-234.

58 Giovanni Luigi Valesio, Coat of arms of the Aldobrandini family on a globe held by Hercules, c. 1598 , Etching, $311 \times 435 \mathrm{~mm}$, London, British Museum (1874,0808.1945). Karen Lloyd is currently studying Valesio's prints in the context of the patronage of cardinal nephews in Seventeenth century Rome.

59 Marcello Fagiolo, "Vignola e Maccarone nei giardini vaticani," in Studi su Jacopo Barozzi da Vignola, edited by Anna Maria Affanni and Paolo Portoghesi (Roma: Gangemi, 2011), pp. 145-162 (147). 
ing Julius III and Atlas with the motto "Immane pondus, vires infractae" makes this connection explicit. ${ }^{60}$ Another garden where the Atlas-Hercules iconography was used in two different fountains is that of the Villa Mattei in Rome, which Agucchi mentions in his letter. ${ }^{61}$

Nevertheless, such interpretations - philosophical (Steinberg) and political (D'Onofrio) - are not clearly articulated in Agucchi's letter of 1620/21, which remains the most important piece of evidence regarding the fountain's initial conception. Moreover, Clement VIII, Pietro's uncle, had died almost fifteen years earlier, in 1605 , so the nepotistic relationship so evidently embodied by the Atlas-Hercules story might not be so central after all. That the ageing cardinal - he would die in February 1621 - was clearly at the end of his career renders that reading all the more disconnected from the political reality of the time.

In his letter to the cardinal, Agucchi mentions the Mattei fountain, but states that the way it works does not reflect the real nature of the heavens:

The figure of Atlas, or Hercules, holding up the sky, is an invention of others used for fountains, but with little judgment, if I mistake not, because to bring out a jet of water from the top of the celestial sphere so that it falls back on the top of the same sphere, as seen in the Mattei garden, is something that does not belong to the nature of the sky, and is not plausible in any way. ${ }^{62}$

Equally, he insists that the sphere should be decorated with the stars, the celestial equator and the zodiac "as they appear in the sky," specifying "with the circle of the equator and the zodiac, and full of stars, some large, some small, as they appear in the sky, and that for each one of them water should gush out from all sides." ${ }^{33}$ Thus, Agucchi is concerned with the astronomical correctness

6o Alessandro Nova, The Artistic Patronage of Pope Julius III (1550-1555): Profane Imagery and Buildings for the De Monte Family in Rome (New York and London: Garland, 1988), pp. $27-28$.

61 On the Mattei fountains, see Fagiolo, "Vignola e Maccarone" (cit. note 59), pp. 155-158.

62 "La figura di Atlante, overo di Hercole, che sostiene il cielo, è inventione da altri adoperata in fontane, ma con poco avedimento, se io non erro, perché il fare uscire un capo d'acqua dalla cima dell'orbe celeste perché ella tornia dader su la medema cima dell'orbe, come si vede al giardino de' Mattei, è opera non appartenente alla natura del cielo, e non verisimile in maniera alcuna," D'Onofrio, La Villa (cit. note 16), pp. 121-122.

63 " [...] col cerchio dell'equatore e zodiaco e pieno di stelle, parte grandi, parte piccole come son nel cielo et per ciascuna stella gittasse l'acqua da ogni lato," ibid. 
or verisimilitude of his representation, which should not appear scientifically implausible. As for the significance he gives to the group, it is neither political nor explicitly philosophical: "It expresses the study of astronomy and the contemplation of celestial things, and the falling waters signify the wisdom [sapienza] and happiness [felicità] given to mankind." ${ }^{4}$

\section{$4 \quad$ The Scientific Interests of Giovanni Battista Agucchi}

At the Villa Belvedere, the great number of mechanical "marvels," the sundials and the special attention given to the celestial globe must all be understood in the light of Agucchi's passion for mathematics, astronomy and natural philosophy in general. ${ }^{65}$ Secretary and maggiordomo to Cardinal Pietro Aldobrandini since 1596, Agucchi is well known to art historians as a letterato, a friend of Annibale Carracci and a possible adviser for the pictorial programme of the Camerino of the Palazzo Farnese, where Hercules supporting Atlas' sphere is depicted on the vault between the figures of Ptolemy and Euclid. ${ }^{66} \mathrm{He}$ is also famous for having devised a concept of ideal beauty that would be taken up more fully by Giovanni Pietro Bellori some years later. ${ }^{67}$ To historians of science, however, Agucchi might be remembered as a dilettante astronomer of great skill and knowledge and a passionate interlocutor of Galileo, with whom he exchanged letters from 1611 to 1621 - exactly the period during which the final programme of the Villa Aldobrandini was being elaborated and executed. ${ }^{68}$ As a member of the Accademia dei Gelati and a

64 "Si esprima con quella non solo lo studio dell'astronomia, ma la contemplatione delle cose celesti, e l'acque cadenti che significano la sapienza e la felicità mandate agli huomini," ibid.

65 To my knowledge, Marcello Fagiolo (Villa Aldobrandina (cit. note 16), p. 70) is the only scholar who has pointed out this connection, however briefly.

66 John Rupert Martin, "Immagini della Virtù: The Paintings of the Camerino Farnese," The Art Bulletin, 1956, 38, 2:91-112, p. 104.

67 A few essential titles are: Denis Mahon, Studies in Seicento Art and Theory (London: Warburg Institute, 1947), pp. 109-154, 231-275; Silvia Ginzburg, Nuove ricerche su Giovanni Battista Agucchi, PhD diss. (Università di Pisa, 1995); eadem, "Domenichino e Giovanni Battista Agucchi," in Domenichino 1581-1641, exhibition catalogue (Roma, Palazzo Venezia), edited by Richard E. Spear and others (Milano: Electa, 1996), pp. 121-137.

68 For Agucchi's scientific interests and his contacts with Galileo, see Antonio Favaro, "Amici e corrispondenti di Galileo Galilei," Atti del Reale Istituto Veneto di scienza, lettere ed arti, 1903-1904, 63, 2:167-187; Panofsky, Galileo as a Critic (cit. note 1), pp. 38-41; Stillman Drake, Galileo at Work: His Scientific Biography (Chicago: Chicago University Press, 1978), 
great admirer of Galileo, although never a Copernican, Agucchi was a staunch supporter of the new science based on the direct observation of the heavenly bodies. In matters of astronomy, he rejected the Aristotelian approach and even cast doubt on the authority of the Holy Scriptures, at least where astronomical phenomena were concerned. Such an opinion was voiced in one of his astronomical works, entitled Della penetrazione e corruttibilità del cielo (1611), which opened with a daring sentence: "Not all judgments contained in the Scriptures are entirely true." ${ }^{69}$ His main goal was to demonstrate "that it is not contrary to the authority of Holy Scripture to show that the sky is penetrable and corruptible, but that these [the penetrability and corruptibility] agree with it [the Holy Scripture]. ${ }^{70}$ His arguments thus anticipate Galileo's famous Copernican letters, written between 1612 and 1615. Della penetrazione constitutes one of the most interesting documents showing the openness of mind of some cultivated members of the Roman clerical elite before Galileo's trial. ${ }^{71}$ This is not to say, of course, that the Catholic Church with respect to its treatment of science was free of tensions. One might point to the fact that the overall situation was rather complicated. The cultural constellation discussed takes place in the decades of Italian history which witnessed a decisive turn towards censorship and repression in the Church's attitudes to the new astronomy and other innovative forms of early modern natural philosophy (Bruno, Della Porta, Campanella) and that the Aldobrandini family and also Agucchi were important political actors in this process.

Beside his literary, artistic, moral and philosophical writings, Agucchi produced other astronomical works, such as Osservazioni sopra le cose di nuovo scoperte in cielo and De cometis tractatus et de comete viso 1618 . He also wrote a treatise on meteorology (De rebus meteorologicis) and one on cosmography

pp. 175-176, 191, 211-212.

69 "Non tutte le sentenze contenute nella Scrittura sono vere del tutto," Biblioteca Apostolica Vaticana, Vatican City, Ms. Ottob. Lat. 2484, Giovanni Battista Agucchi, Della penetrazione e corruttibilità del cielo (1611), fol. $237^{\mathrm{r}}-251^{\mathrm{v}}$, fol. $239^{\mathrm{v}}$.

70 “[...] che non si contrasta all'autorità della Sacra Scrittura mostrandosi che'l cielo è penetrabile e corruttibile, ma si è con essa d'accordo," Agucchi, Della penetrazione (cit. note 69), fol. $239^{\mathrm{r}}$.

71 On Agucchi's Della penetrazione e corruttibilità del cielo, see Ginzburg, Domenichino e Giovanni Battista Agucchi (cit. note 67), pp. 128-129, and Massimo Bucciantini, “Teologia e nuova filosofia. Galileo, Federico Cesi, Giovambattista Agucchi e la discussione sulla fluidità e corruttibilità del cielo," in Sciences et religions de Copernic à Galilée (1540-1610) (Roma: École Française de Rome, 1999), pp. 411-442. 
(Trattato di cosmografia fatto per servizio della Congregazione di Propaganda Fide). ${ }^{72}$

The mathematician Luca Valerio introduced Agucchi to Galileo at the Trinità dei Monti in Rome in April 1611, and Agucchi thereafter involved himself deeply in the observation of the satellites of Jupiter that Galileo had discovered two years previously. On 13 June 1613, he sent Galileo a memorable letter in which, although praising his work, he warned him not to waste time in controversial questions about the Copernican system, which to him was not acceptable because it led to a conception of the world as being of "infinite magnitude," along the lines of the contention that cost Giordano Bruno his life on 17 February 16oo. Agucchi added that he would rather follow Tycho Brahe's system, according to which the Earth is at the centre of the universe, the Sun, Moon and stars revolve around the Earth, and the other five planets revolve around the Sun. ${ }^{73}$ This was the system that the Church adopted, essentially through the influence of Jesuit scientists such as Christoph Clavius, during the very same period when Agucchi was corresponding with Galileo, from 1611 to $1620 .{ }^{74}$

The choice of Atlas and Hercules for the Teatro d'Acqua, a personification of "astronomy and the contemplation of celestial things," thus appears to be perfectly in tune with Agucchi's scientific interests at the time. A closer look at the fountain's iconography can help establish this connection even more firmly.

Agucchi, in his letter, suggests that only one statue, Atlas or Hercules, should be displayed in the central niche ("It would be appropriate to fill the great niche with one large statue only"). ${ }^{75}$ Likewise, at the Vatican, at the Villa Mattei, and on the ceiling of the Camerino Farnese, only one figure is holding the celestial sphere. Yet, eventually, both figures were represented in the central niche. Why this change? What could have inspired it? D'Onofrio noted that the encounter between the two heroes took place near the Garden of the Hesperides. The episode thus suggested an eloquent comparison between the mythical garden and the Aldobrandini garden. ${ }^{76}$ Both D'Onofrio and Schwager deduced from

72 Giacomo Filippo Tomasini, Elogia virorum literis et sapientiae illustrium ad vivum expressis imaginibus exornata (Padova, 1644), pp. 14-28, pp. 27-28.

$73 \quad$ og, XI, pp. $53^{2-535}$.

74 Isabelle Pantin, "New Philosophy and Old Prejudices: Aspects of the Reception of Copernicanism in a Divided Europe," Studies in History and Philosophy of Science, 1999, 30:237-262, p. 247 .

75 "Il nicchione poi verrebbe convenevolmente riempito con una grande statua sola," D'Onofrio, La Villa (cit. note 16), pp. 121-122.

76 Ibid., p. 123. 
this that the two female figures to the left of the group should be identified with the Hesperides, the daughters of Atlas. However, Steinberg identified correctly, I believe - the objects those two figures are holding as mathematical instruments - a compass and perhaps an armillary sphere or a tellurium thus reinforcing the astronomical iconography of the group (Fig. 5a). Steinberg proposed that the attitudes of Hercules and Atlas point towards a specific source: Philostratus' Imagines (II.20), where Hercules is described as eagerly reaching up with extended arms to take the sphere of the heavens from Atlas' shoulders. ${ }^{77}$ However, this does not help us to interpret the meaning of the episode. In fact, Steinberg overlooked an important iconographic tradition, which may have played a role in the final choice for the grouping of the two heroes, namely the astronomical one.

As Volker Remmert has recently shown, the iconographic association between Atlas and Hercules developed mostly in the context of astronomical texts and illustrations and came to symbolise, at the turn of the century, the new astronomical science as opposed to the ancient Ptolemaic view of the universe. Atlas stands for the old Ptolemaic view, and Hercules for the new conception of the universe, based on empirical observation. ${ }^{78}$ Remmert has traced the iconography of Atlas and Hercules through Antiquity and the Middle Ages up to the early modern period, showing that the two figures were intellectualised to become important personifications of astronomy. Atlas, a king, was defined by most as the founder of astronomy or astrology and Hercules was described as an avid and virtuous scholar of the sciences. The Danish nobleman Tycho Brahe, the most successful and famous astronomer of his time and a master of self-promotion, appropriated the story. In a poem written in 1597, he associates himself with Hercules, having triumphed over King Atlas as a personification of Ptolemy, but also over King Alfonso and Copernicus. As Remmert writes,

In this conception, the Atlases, Ptolemy, Alfonso and Copernicus, represented the old astronomy, which had not been based on such longlasting and systematic observations as Brahe himself had undertaken. [...] Imbued with the unique importance of his own achievements, he con-

77 Steinberg, "The Iconography of the Teatro" (cit. note 19), p. 458. Compare this, for instance, with the illustration of this episode in Philostratus, Les Images, translated by Blaise de Vigenère (Paris: Chez la veuve Abel Langelier, 1614), p. 469.

78 Volker Remmert, "The Visual Legitimization of Astronomy during the 16th and 17th Centuries: Atlas, Hercules and Tycho's Nose," in Remmert, Picturing the Scientific Revolution (cit. note 11), pp. 127-165.

NUNCIUS $30(2015) 124-160$ 
sciously styled himself as he who had taken on the mantle of Hercules and become the standard-bearer of the new astronomy. ${ }^{79}$

The association between Brahe and Hercules was made frequently thereafter. In his astronomical treatise A Tutor to Astronomie and Geographie where, as we have seen, an image showing Hercules holding the celestial sphere derives from Jacques Sarrazin's great statue at Villa Aldobrandini, Joseph Moxon celebrated Tycho Brahe as Hercules the Second. ${ }^{80}$ Likewise, on the title page of Johannes Bayer's Uranometria (Augsburg, 1603), and again in Andrea Argoli's Tabulae primi mobilis, published in Rome by Facciotti in 1610 and a book almost certainly known to Agucchi, Hercules is given the features of Tycho Brahe, with his unmistakable artificial nose.

It is thus possible that Giovanni Battista Agucchi, himself an active supporter of the new astronomy and an adept of Brahe's system, was aware of the meaning given to the Atlas-Hercules story in scientific circles, and that this knowledge might have played no small part in the final choice for the iconography of the Teatro d'Acqua at the Villa Aldobrandini. Yet it should be emphasised that this kind of astronomical imagery became absorbed into a more complex and more open meaning - at the same time emblematic, political and philosophical whose main purpose was the glorification of the villa's owner: a telling example of the fluidity of meaning assigned to works of art in early modern gardens. ${ }^{81}$

\section{$5 \quad$ Conclusion}

It may be argued that the origin of the Atlas-Hercules iconography at the Villa Aldobrandini is bound up with the contemporary scientific interests of

79 Ibid., p. $15^{2}$.

8 Ibid., pp. 139-144.

81 A few decades later, we encounter such combination of heraldic praise, political propaganda and scientific curiosity during the Royal Wedding of Cosimo the Third of Tuscany and Marguerite d' Orléans, held in the Amphitheatre of the Boboli gardens in Florence. A giant Atlas was seen to appear from a rocky landscape, carrying the celestial sphere on his shoulder. The globe opened during the various intermezzi, which accompanied the entry of Cosimo as Hercules followed by two carriages representing the Sun and the Moon. Inside the Atlas, four knights represented the Medicean Stars, the satellites of Jupiter discovered by Galileo in 1610. See Luigi Zangheri, "Il maxiautoma dell'atlante e Ferdinando Tacca," Psicon, 1976, 3:116-123. The full description of the apparato is published in Giovanni Andrea Moniglia, Il mondo festeggiante (Firenze: Nella Stamperia di s.A.s., 1661). The stelle medicee are described pp. 49-50. 
Agucchi and his patrons in astronomy and in natural philosophy generally. This underlying theme helps to explain the function that the two sundials might have played within the symbolic and scientific economy of the villa. Wonder and science are here closer than they will ever be again. To take but one example, the rainbow and the tempest artificially produced in the Aldobrandini Teatro d'Acqua were tricks intended to dazzle visitors, yet they also invited intellectual speculation, especially for a man like Agucchi, who had written a scientific treatise on meteorology. 82

Within the space of the garden, it is this quest for knowledge, for answers about the workings of nature, that was seen as a virtuous path for natural philosophers and aristocrats such as Giovanni Battista Agucchi and Pietro Aldobrandini. Agucchi gives such a meaning, for instance, to the statue of Apollo located inside the villa: it serves as a reminder of "virtuous things and the liberal arts, as Apollo was thus upheld [i.e. as an emblem] by the ancients." 83 It is also in this sense, I believe, that one should read Agucchi's words when he wrote that the study of astronomy, the contemplation of celestial things and the elaborate movement of water lead to sapienza - as both wisdom and knowledge - and to felicità. Of course, in the context of seventeenth-century papal Rome, such a thirst for knowledge should be also understood as a quest for divine wisdom and the knowledge of God. ${ }^{84}$ In this regard, Agucchi's programme for the Villa Aldobrandini anticipates remarkably John Evelyn's own great project, the Elysium Britannicum, in which science and progress were inseparable from the desire to know God better through the study of nature and thus to improve the corrupted relationship between nature and mankind that resulted from the Fall. ${ }^{85}$ As Rebecca Michaels put it, "Evelyn's purpose is not

82 On this topic, see further Philip Fisher, Wonder, the Rainbow, and the Aesthetics of Rare Experiences (Cambridge, MA: Harvard University Press, 1999).

83 "[...] le virtuose cose e le arti liberali, come Apollo a questo era dall'Antichi proposto," D’Onofrio, La Villa (cit. note 16), p. 96.

84 One might usefully compare the programme of Villa Aldobrandini as analyzed here with that of the garden of the Castello reale di Racconigi near Turin, intended to promote contemplation of celestial astronomy as well as of human philosophy. The programme is described in Emmanuele Tesauro, Il cannocchiale aristotelico (Torino: 1670), pp. 710-711. See Elisabeth MacDougall, "Ars Hortulorum: Sixteenth Century Garden Iconography and Literary Theory in Italy," in The Italian Garden, edited by David Coffin (Washington, Dumbarton Oaks, 1972), pp. 37-59, p. 39 and, on its devotional aspect, Judi D. Loach, "Le jardin céleste de Racconigi: la conception et l'usage d'un jardin d' apparence laïque de la Contre-Réforme," in Flore au paradis, edited by Paulette Choné and Bénédicte Gaulard, Glasgow emblem studies 9 (Glasgow: 2004), pp. 37-48.

85 Hunt, Garden and Grove (cit. note 40), pp. 8o-81. See also Denis Ribouillault, "Labeur 
only to instruct his audience on the construction of an Italianate garden, but to provide a didactic manual on Christian worship in Nature that incorporates both meditation on Biblical passages and the scientific observation of natural phenomena." ${ }^{86}$ That Evelyn should begin the Elysium Britannicum by invoking Adam in the Garden of Eden is hence no more surprising than that Cardinal Aldobrandini should have episodes from Genesis painted inside his splendid villa by Cavaliere d'Arpino. ${ }^{87}$ Likewise, the felicità that Agucchi assigned to the inhabitants of the cardinal's ideal garden can be understood in terms of one of Evelyn's statements: “... to define a Garden now, is to pronounce it ... A place of all terrestrial enjoyments the most resembling Heaven, and the best representation of our lost felicitie." 88

The study of garden sundials raises several interesting questions regarding the history of scientific instruments. Let us close by mentioning two of these, one pertinent to social history, the other related to space and intermediality.

Within the garden, boundaries blurred between the instrument as an image carrying specific meaning(s), the instrument as a tool for actual measuring, and, in some instances, the instrument as a surface decorated with images. As such, a garden sundial embodies different, overlapping horizons of perception. The fact that they are so clearly entangled in our case study shows that, in the Early Modern period, the appreciation of science continues to be profoundly embedded in mythological or Christian iconography and aesthetic values inherited from humanist thinking. The mythological and antiquarian nature of the astronomical iconography at Villa Aldobrandini also attests that interest in and discourse (in Italian conversazione) about science for the aristocratic elite cannot be dissociated from interest in and discourse about art, literature and poetry. They are the same expression of an increasing eagerness of the courtier and the nobleman to enhance his status by demonstrating his knowledge and his intellectual refinement. As we have seen, the polymath Agucchi is a clear embodiment of such an idea. Likewise, it is fascinating to

et rédemption: paysage, jardins et agriculture sacrés à Rome, de la Renaissance à l'âge baroque," in Sacred Landscape. Landscape as Exegesis in Early Modern Europe, edited by Michel Weemans and Denis Ribouillault (Firenze: Olschki, 2011), pp. 233-282, p. 279.

86 Rebecca A. Michaels, John Evelyn's 'Elysium Britannicum': Transplanting the Baroque Italian Garden to Restoration England, Master's thesis (University of Victoria, 2004), pp. 125149, p. 126.

87 Clare Robertson, "Silvio Antoniano and the Painted Decoration of the Villa Belvedere at Frascati," Römisches Jahrbuch der Bibliotheca Hertziana, 2003-2004, 35:417-430.

88 Evelyn, Elysium Britannicum (cit. note 53), p. 31. 
encounter in the garden at Frascati, walking alongside Cardinal Pietro Aldobrandini, a figure like Giovanni Battista Ciampoli, at once a Copernican versed in mathematics, an eminent member of the Roman curia and a prolific poet. ${ }^{89}$

Thus, it is to the social constructedness of the discourse of scientific connoisseurship that scholars interested in the iconography of scientific instruments should be paying close attention. ${ }^{90}$ Indeed, we may recall that most of the philosophical or mathematical instruments decorated with images in the early modern period were conceived as luxurious goods for powerful aristocrats. In the space of the garden, the interesting problem of distinguishing between tricks or pure ornaments on the one hand, and what we today call 'scientific instruments' on the other, belong to the same range of questions Panofsky and Koyré raised concerning the relationship between aesthetic attitude and scientific discourse. Are complex hydraulic fountains and sundials, as garden ornaments, also to be considered as having had an impact on the way one thought about and considered the natural world 'scientifically'? For instance, were the jets of fresh air sustaining metal balls in the Stanza dei Venti only there to amaze? May they not also be considered as a 'theatralization' of certain properties of natural elements such as the resistance of the air, on which scientists like Galileo were conducting research in those very same years? If we read again Cortesi's advice in the De Cardinalatu concerning suitable subjects for garden paintings, it is clear that the fact that these objects required mathematical knowledge to be made and understood greatly enhanced their appeal, for it fostered the cultivation of the mind. In other words, the presence of these artefacts was not only regarded as delightful to the senses but also to the intellect. ${ }^{91}$

89 On the complex figure of Giovanni Battista Ciampoli, see Federica Favino, Pietro Sforza Pallavicino e l'«invidiabil conversatione» di monsignor Giovanni Battista Ciampoli, Ph.D. diss., University of Naples Federico II, 1996 and eadem, La filosofia naturale di Giovanni Ciampoli (Firenze: Olschki, 2014). Ciampoli worked on a vast project "aimed - according to Federica Favino - to 'regenerate' the new levers of papal bureaucracy, by purifying their minds of the taint of Aristotle's philosophy. On the other hand, it aimed to re-establish the whole encyclopaedia of human knowledge - natural philosophy, ethics, politics, linguistics - on the basis of a radical empiricism and of sensorial perception."

9o A similar fruitful approach is that of Andrew Dell'Antonio concerning listening practices and discourse about music in early modern Rome. See Andrew Dell'Antonio, Listening as Spiritual Practice in Early Modern Italy (Berkeley, Los Angeles, London: University of California Press, 2011), pp. 1-13.

91 See further Paula Findlen, "Jokes of nature and jokes of knowledge: The playfulness of scientific discourse in early modern Europe," Renaissance Quarterly, 1990, 43:292-331.

NUNCIUS $30(2015) 124-160$ 
Such an ambivalent attitude or, we might say, the dual response of the garden visitor to its environment has a long history. Traditionally, gardens are places for relaxation and pleasure, but also for the practice of philosophy. To the aristocratic elite gathered in gardens, therefore, sundials were not so much there to measure time as to provide a 'model of the universe' (Michel Serres) thanks to which one could exchange ideas and display knowledge. ${ }^{92}$ It served to demonstrate rather than to enquire. Furthermore, it gave material shape, tangible visibility to something that is by definition elusive, - the sun. As such, it functioned as a potent mark of authority, a symbol of power over nature, a sign directly associated with the capacity of the owner to rule over territories and communities.

In the garden, the sundial cannot be kept apart from other features, such as hydraulic mechanisms, painted perspectives or secret gardens with rare plants and flowers. These instruments/ornaments organise a web of interconnected themes that, taken as a whole, express a specific view of the relationship between man and nature. Thus, the instrument can almost never be considered as an isolated object in the early modern period. It is always part of a greater collection, be it in a garden, a cabinet of curiosity, the title page of a book, or a museum. Therefore, an intermedial approach seems to be required to understand these artefacts and the way they create connections, relations, with other objects and the spaces in which they are used and displayed. ${ }^{93}$ Finally, looking at garden sundials should also encourage scholars to consider not just their "meaning," but the way they, as material objects, engage the viewer into a sensory and spatial experience. As we have seen, the sundial at the villa Aldobrandini functioned like the rose wind located at the bottom corner of a large map. They situate the viewer, not only intellectually, but also physically, within a larger horizon, both horizontally (the landscape view) and vertically (the sky, the cosmos).

92 Michel Serres, "Gnomon. Les débuts de la géométrie en Grèce," in Éléments d'histoire des sciences, edited by Michel Serres (Paris: Bordas, 1986), pp. 95-153.

93 On this topic concerning Baroque Rome, see especially Koen Vermeir, "Athanasius Kircher's magical instruments: an essay on 'science', 'religion', and applied metaphysics," Studies in History and Philosophy of Science, 2007, 38:363-400, pp. 365-368. 